OPEN ACCESS

Edited by:

Peter Dunfield,

University of Calgary, Canada

Reviewed by:

Marshall Wayne Bowles, University of Bremen, Germany

Chris Kempes,

SETI Institute, USA

Peter Dunfield

University of Calgary, Canada

*Correspondence: Josef Zeyer josef.zeyer@env.ethz.ch

Specialty section: This article was submitted to

Extreme Microbiology, a section of the journal Frontiers in Microbiology

Received: 17 September 2015 Accepted: 04 December 2015 Published: 22 December 2015

Citation Meola M, Lazzaro A and Zeyer J (2015) Bacterial Composition and Survival on Sahara Dust Particles Transported to the European Alps. Front. Microbiol. 6:1454. doi: 10.3389/fmicb.2015.01454

\section{Bacterial Composition and Survival on Sahara Dust Particles Transported to the European Alps}

\author{
Marco Meola, Anna Lazzaro and Josef Zeyer* \\ Environmental Microbiology, Institute of Biogeochemistry and Pollutant Dynamics, Environmental Systems Science, Swiss \\ Federal Institute of Technology, ETH Zurich, Zurich, Switzerland
}

Deposition of Sahara dust (SD) particles is a frequent phenomenon in Europe, but little is known about the viability and composition of the bacterial community transported with SD. The goal of this study was to characterize SD-associated bacteria transported to the European Alps, deposited and entrapped in snow. During two distinct events in February and May 2014, SD particles were deposited and promptly covered by falling snow, thus preserving them in distinct ochre layers within the snowpack. In June 2014, we collected samples at different depths from a snow profile at the Jungfraujoch (Swiss Alps; $3621 \mathrm{~m}$ a.s.l.). After filtration, we performed various microbiological and physicochemical analyses of the snow and dust particles therein that originated in Algeria. Our results show that bacteria survive and are metabolically active after the transport to the European Alps. Using high throughput sequencing, we observed distinct differences in bacterial community composition and structure in SD-layers as compared to clean snow layers. Sporulating bacteria were not enriched in the SD-layers; however, phyla with low abundance such as Gemmatimonadetes and Deinococcus-Thermus appeared to be specific bio-indicators for SD. Since many members of these phyla are known to be adapted to arid oligotrophic environments and UV radiation, they are well suited to survive the harsh conditions of long-range airborne transport.

\section{Keywords: Saharan dust event, Jungfraujoch, snow, bioaerosols, MiSeq Illumina, Biolog, UV radiation, desiccation} stress

\section{INTRODUCTION}

Aerosols are suspended liquid, solid or multiple-phase particles of condensed matter in a gaseous medium. They vary in composition (i.e., biological or mineral), size $(0.001-100 \mu \mathrm{m})$ and shape (Kulkarni et al., 2011). In the past few years, aerosols have received increasing attention as important agents of climate change (Solomon et al., 2011).

Arid regions such as deserts are the major source of mineral dust particles in the atmosphere. There, dust particles are uplifted by storm activity and transported as aerosols to altitudes above 5000 meters above sea level (m a.s.l.) (Prospero et al., 2005). The Sahara Desert in Africa is the world's main source of mineral aerosols (Goudie and Middleton, 2006) and has been estimated to contribute $630-710 \mathrm{Mt}$ to the atmosphere each year (D'Almeida, 1986). Approximately $60 \%$ of the Saharan dust emissions are transported southward, $25 \%$ westward to the Atlantic, 5\% eastward to the Middle East and 10\% northward to Europe (Shao et al., 2011). 
Up to $25 \%$ of the total global aerosol mass is composed of biological particles, or bioaerosols (Jaenicke, 2005). The first descriptions of bioaerosols were provided by Charles Darwin, who observed "67 different organic forms" in fine dust particles that were deposited on the Beagle during his journey across the Atlantic Ocean in 1833 (Darwin, 1846). Generally, bioaerosols contain skin fragments, fur fibers, protein crystals, pollen, plant fragments, spores, viruses, algae, fungi, and bacteria, and can be free-floating or attached to mineral aerosols (Després et al., 2012; Deleon-Rodriguez et al., 2013). Bioaerosols such as viruses, bacteria and fungi have gained increasing interest because of their potential to spread pathogens over long distances (Prospero et al., 2005; Griffin, 2007; Polymenakou, 2012). They have also been linked with atmospheric processes (Morris et al., 2011; S̆antlTemkiv et al., 2013). For example, airborne bacteria can serve as ice-nuclei during snow precipitation (Amato et al., 2007b; Bowers et al., 2009; Hiranuma et al., 2015).

The long-distance transport of viable bacteria in conjunction with mineral aerosols may represent a way for bacteria to colonize new environments and contribute to an increase in diversity at remote terrestrial and aquatic habitats (Barton et al., 2010). In fact, airborne bacteria from Sahara dust (SD) particles collected on Darwin's Beagle in the Nineteenth century were shown to be viable 150 years later (Gorbushina et al., 2007). However, the extent to which the organisms remain viable or active after the aerial dispersal are still uncertain, as well as their potential to establish a colony after deposition (Pointing and Belnap, 2012). Due to the harsh conditions associated with airborne transport (e.g., desiccation stress, UV exposure, oligotrophic conditions, and low temperatures) (Smith et al., 2009), only specially adapted taxa are able to survive the journey to a new environment. Sporulation or pigmentation might help to protect bacteria against the harsh conditions that prevail during transport (Tong and Lighthart, 1997). For example, Janthinobacterium is a bacterium that is commonly detected in air samples and produces an indigo-purple pigment (Fahlgren et al., 2010).

To date, airborne bacteria from the Sahara Desert have been sampled along the coast of Greece and southeastern Mediterranean (Griffin et al., 2007; Polymenakou et al., 2008; Katra et al., 2014), in Spain (Sánchez De La Campa et al., 2013; Barberán et al., 2014) and in the Caribbean (Griffin et al., 2003; Prospero et al., 2005). Air sampling of bacteria can be performed using techniques such as filtration, impaction, suction, impingement and electrostatic precipitation, each of which presents different advantages and disadvantages for specific downstream biological analyses (e.g., PCR-based techniques) (Mandal and Brandl, 2011). The collection of aerosols, either indoors or outdoors, requires a understanding of the physical principles influencing the collection of suspended particles that can cause quantitative and qualitative biases (Després et al., 2012). Notably, the collection of bioaerosols requires special handling procedures to avoid damaging the cells during the collection process (e.g., dehydration stress) (Després et al., 2012). Finally, the timing and duration of Saharan dust events (SDEs) remains difficult to predict, hampering the ability of researchers to recover an air volume suitable for microbiological analyses.
Bacteria deposited on snow allow researchers to circumvent the drawbacks of air sampling. Both the physical integrity and the potential viability of the bacterial cells are preserved, as they are collected at freezing temperatures from within the snowpack. High-altitude locations above the influence of the planetary boundary layer are ideal for detecting deposited Sahara dust (SD) particles because the potential contamination from anthropogenically-derived aerosols after deposition is minimal (Griffiths et al., 2014; Nicolás et al., 2014).

Most SDE studies performed in the Alps have focused on mineralogical and chemical aspects (Sodemann et al., 2006; Thevenon et al., 2009); microbiological analyses are still lacking. The first attempts in this direction were made by GonzálezToril et al. (2009) and Chuvochina et al. (2011a) on the Mont Blanc glacier. However, no details regarding the physicochemical parameters of the snow, the position of the Sahara dust layers (SD-layers) within the snowpack or the geochemical characteristics of the dust particles were presented in these studies. Despite the valuable contribution of these preliminary studies, the low sequencing depth achieved by small clone libraries makes it difficult to draw solid conclusions about the bacterial community structures associated with SDEs. Moreover, knowledge is still limited regarding the viability and metabolic activity of the bacteria transported from the Sahara Desert to the Alps.

The region of Jungfraujoch, located in the Swiss Alps at about $3600 \mathrm{~m}$ a.s.l., lies above the influence of the planetary boundary layer and is therefore a highly advantageous location for studying aerosols transported from the Sahara Desert to the European Alps. SDEs are regularly monitored in real-time at the Jungfraujoch meteorological station. Such events are very common in spring (March-June) and autumn (OctoberNovember) but rare in summer and winter (Collaud Coen et al., 2004; Papayannis et al., 2008; Conen et al., 2015; Flentje et al., 2015). However, an exceptionally long-lasting ( $40 \mathrm{~h}$ ) winter SDE deposited dust particles originating from the Sahara Desert on snow in the Swiss Alps in February 2014. The SD particles and the associated bacteria were covered by fresh snow 3 days after deposition. This rare winter SDE offered the unique opportunity to sample a well-preserved SD-layer within the snowpack. In addition to the winter SDE, a shorter $(22 \mathrm{~h})$ spring SDE in May 2014 deposited dust particles just before snowmelt. Together, these deposits allow for the comparison of SDEs occurring in different seasons and originating from different regions of the Sahara Desert.

The aim of this study was to characterize bacterial communities within the SD-layers preserved in snow through a combination of high throughput sequencing and incubations for microbiological metabolic activity using MiSeq Illumina ${ }^{\circledR}$ and Biolog EcoPlate ${ }^{\mathrm{TM}}$, respectively. We compared different layers from a snow profile taken at Jungfraujoch in which we could distinguish snow layers containing SD particles from the adjacent clean snow layers (CS-layers). We present the first study to achieve a high resolution sequencing depth and coverage for SDE-associated bacteria in combination with extensive in situ and laboratory analyses of physicochemical and geochemical characteristics of the snow and the particles therein. 


\section{MATERIALS AND METHODS}

\section{Site Description and Sample Collection}

Sampling was conducted at the Jungfraujoch region $\left(46^{\circ} 33^{\prime} 11^{\prime \prime} \mathrm{N} / 8^{\circ} 0^{\prime} 17^{\prime \prime} \mathrm{E}, 3621 \mathrm{~m}\right.$ a.s.l.) on a snow field between the high-alpine Jungfraujoch World Meteorogical Station (No. 06730) and the alpine hut Mönchsjochhütte.

A vertical trench was excavated by a snow groomer to a depth of $220 \mathrm{~cm}$ below the snow surface on 8 June 2014 at 08:00 CEST. Three snow profiles (A, B, and C) at $100 \mathrm{~cm}$ distance to each other were selected for sampling on the shadowy side of the trench. Three replicates for physicochemical and microbiological analyses were taken from the snow profiles by cutting a fresh trench in the snow with a knife sterilized with $70 \%$ ethanol. At each profile, a $3.5 \times 13 \times 13 \mathrm{~cm}$ block of snow was cut at seven depths (J0: $-25 \mathrm{~cm}, \mathrm{~J} 1:-80 \mathrm{~cm}, \mathrm{~J} 2:-120 \mathrm{~cm}, \mathrm{~J} 3:-145 \mathrm{~cm}, \mathrm{~J} 4$ : $-150 \mathrm{~cm}$, J5: $-155 \mathrm{~cm}$, J6: $-170 \mathrm{~cm}$, and J7: $-190 \mathrm{~cm})$ and stored in a sterile freezer bag (Supplementary Figure 1C).

Samples were stored in an ice box in the field and transported to the laboratory, where they were stored at $0^{\circ} \mathrm{C}$. Snow was melted slowly and subsequently transferred into autoclaved laboratory Schott glass bottles and stored at $0^{\circ} \mathrm{C}$ until further analyses (total volume between 300 and $480 \mathrm{ml}$ per field sample).

\section{Physicochemical Parameters}

Physical parameters such as snow temperature and density were measured in situ along the snow profile at 10 and $20 \mathrm{~cm}$ intervals, respectively. Temperature was measured with a Testo 925 temperature sensor (Testo AG, Mönchaltdorf, Switzerland). Density was measured with a snow-weighing method (Goodison et al., 1981). Conductivity and $\mathrm{pH}$ were measured in homogeneously mixed meltwater at room temperature with a Universal Pocket Meter Multi 350i (WTW, Weilheim, Germany) following the manufacturer's instructions.

\section{Backward Trajectory Calculation}

Backward trajectories of air masses were calculated using the Vertical Velocity NOAA HYSPLIT Model and GDAS1 meteorological data (Draxler and Rolph, 2003). SDEs were detected by the Paul-Scherrer-Institute (PSI) using the nephelometer aSSA BR TSI method at the Jungfraujoch as described in Collaud Coen et al. (2004). We assessed the intensity of the SDEs by considering the area of the negative albedo scattering.

\section{Meteorological Data}

Daily maximum and night minimum air temperature $2 \mathrm{~m}$ above the ground was measured at Jungfraujoch $\left(46^{\circ} 32^{\prime} 51^{\prime \prime} \mathrm{N} / 7^{\circ} 59^{\prime} 07^{\prime \prime} \mathrm{E} ; 3580 \mathrm{~m}\right.$ a.s.l.). No snow height data are available from Jungfraujoch. However, snow height was assessed by averaging the data from two meteorological stations at $8.6 \mathrm{~km} \mathrm{NW}$ and $15 \mathrm{~km} \mathrm{SE}$ distance to the Jungfraujoch, respectively: Männlichen ( $46^{\circ} 36^{\prime} 47^{\prime \prime} \mathrm{N} / 7^{\circ} 56^{\prime} 27^{\prime \prime} \mathrm{E} ; 2343 \mathrm{~m}$ a.s.l.) and Eggishorn ( $46^{\circ} 25^{\prime} 36^{\prime \prime} \mathrm{N} / 8^{\circ} 05^{\prime} 34^{\prime \prime} \mathrm{E} ; 2927 \mathrm{~m}$ a.s.l.). Data were supplied by the Federal Office of Meteorology and Climatology MeteoSwiss (IDAweb).

\section{Dust Particle Characterization and Quantification}

Meltwater $(5 \mathrm{ml})$ containing homogeneously suspended dust particles were filtered through a $0.2 \mu \mathrm{m}$ GTTP polycarbonate filter with a vacuum pump (Millipore, Billerica, MA, USA). Samples containing high dust concentrations (J0 and J4) were diluted 1:10 to reduce particle density on the filter. The same procedure was applied to three bedrock samples sampled within $200 \mathrm{~m}$ of the snow profiles (Rock1: $46^{\circ} 33^{\prime} 9^{\prime \prime} \mathrm{N} / 8^{\circ} 0^{\prime} 9^{\prime \prime} \mathrm{E}$; Rock2: $46^{\circ} 33^{\prime} 16^{\prime \prime} \mathrm{N} / 8^{\circ} 0^{\prime} 27^{\prime \prime} \mathrm{E}$, Rock $3: 46^{\circ} 33^{\prime} 16^{\prime \prime} \mathrm{N} / 8^{\circ} 0^{\prime} 20^{\prime \prime} \mathrm{E}$ ) after being ground to powder.

Dust particles were characterized by scanning electron microscopy (SEM) (Jeol 6390LA) at the Institute of Geochemistry and Petrology (ETH, Zurich). Particle chemical analyses from carbon-coated samples mounted on polycarbonate filters were obtained by energy-dispersive X-ray spectroscopy (SEM-EDX), using a solid state EDS detector combined with the Thermo scientific software NSS3 under high vacuum conditions. The SEM was initially equipped with a $\mathrm{W}$-filament that was later changed to an LAB6 crystal. An acceleration voltage of $15 \mathrm{kV}$ was employed for all analyses with a beam current of $2.5 \mathrm{nA}$ and a probe diameter of $1 \mu \mathrm{m}$. The chemical composition of each particle was measured during $15 \mathrm{~s}$ live time. Due to the small size of the dust particles, the excitation volume occasionally exceeded the size of the dust particles, which resulted in analytical artifacts that could not be circumvented. All analyses are therefore normalized to a carbon-free basis.

Mineral phases were defined based on a modified plot of Moreno (2003): quartz and low-Al-content silicates (x: 1.0-1.3, y: 0.0-0.2); feldspars (x: $0.8-1.2, y: 0.2-0.5)$; illite (x: 1.3-1.6, y: $0.6-0.9$ ); kaolinite (x: 1.6-2.5, y: 0.85-1.2); montmorillonite ( $\mathrm{x}$ : $1.3-1.5, \mathrm{y:} 0.4-0.6)$.

Organic and inorganic particles were quantified using a BD Accuri C6 flow cytometer (BD Biosciences, San Jose, USA). Meltwater $(200 \mu \mathrm{l})$ was fixed with glutaraldehyde (SigmaAldrich, Buchs, Switzerland), stained with $2 \mu$ l of Sybr ${ }^{\circledR}$ Green (Life Technologies, Zug, Switzerland) and incubated for $10 \mathrm{~min}$ at $37^{\circ} \mathrm{C}$.

\section{Isolation of Total DNA}

In an attempt to improve the recovery of DNA from spore-forming bacteria and to compensate for low biomass concentrations, two slightly different DNA extraction methods were applied.

Method MOBIO UltraClean: $100 \mathrm{ml}$ of homogeneously mixed meltwater was filtered through a $0.2 \mu \mathrm{m}$ sterile nylon membrane with a vacuum filtration system (model 87006-076, VWR, PA, USA) (Supplementary Figure 1D). Total DNA was isolated using the MOBIO UltraClean ${ }^{\mathrm{TM}}$ DNA Isolation Kit (Mobio Laboratories, CA, USA) according to the manufacturer's instructions with the following modifications: filters were washed over night in a tube (Falcon 15) with $60 \mu$ l of solution S1, $600 \mu \mathrm{l}$ of solution IRS and $400 \mu \mathrm{l}$ of bead solution. To completely detach the particles from the filters, the tubes were horizontally centrifuged for $30 \mathrm{~min}$ at maximum speed. Thereafter, the tubes were sonicated for $10 \mathrm{~s}$ in a water bath at room temperature and immediately placed on ice for $20 \mathrm{~s}$. Sonication was repeated 
twice. Finally, liquid was transferred into the bead-containing tubes, incubated for $10 \mathrm{~min}$ at $65^{\circ} \mathrm{C}$ and processed following the manufacturer's instructions.

Method MOBIO PowerWater: The remaining volume (variable in each sample between 20 and $280 \mathrm{ml}$ ) of homogeneously mixed meltwater was filtered through a $0.2 \mu \mathrm{m}$ sterile nylon membrane with a vacuum filtration system (model 87006-076, VWR). Due to plugging, two filters were used for samples containing SD particles. Filters were cut in two halves. One half of each filter was used for extraction using the MOBIO PowerWater ${ }^{\mathrm{TM}}$ DNA Isolation Kit (Mobio Laboratories) according to the manufacturer's instructions with the following modifications: PowerWater ${ }^{\circledR}$ Bead Tubes were heated at $65^{\circ} \mathrm{C}$ for $10 \mathrm{~min}$ as indicated by the alternate lysis method. Thereafter, the tubes were shaken horizontally for $1 \mathrm{~h}$ at maximum speed. DNA was eluted in $50 \mu \mathrm{l}$ PW6 and stored at $-20^{\circ} \mathrm{C}$.

The DNA of all three extractions (1 extraction with method MOBIO UltraClean and 2 extractions with method MOBIO PowerWater) was pooled prior to further processing.

Extracted DNA was quantified with the Qubit ${ }^{\circledR}$ Fluorometer dsDNA HS Assay Kit and normalized to the total volume of the filtered meltwater.

\section{Low Cycle Amplicon PCR}

Multiplex MiSeq Illumina ${ }^{\circledR}$ sequencing was performed with lowcycle amplification, Nextera indexing per the instructions of the Genetic Diversity Center (GDC; ETH Zurich, Switzerland).

For PCR amplification, the universal forward primer Bakt_341F (Accession Number pB-03844) 5' CCTACGGGNGGCWGCAG-3' and universal reversed primer Bakt_805R (pB-03845): 5'-GACTACHVGGGTATCTAATCC-3' (Herlemann et al., 2011) were modified for subsequent MiSeq Illumina ${ }^{\circledR}$ sequencing of the $16 \mathrm{~S}$ rRNA gene hypervariable region $\mathrm{V} 3-\mathrm{V} 4$ by adding the overhang (italic) and an insertion of zero to three nucleotides between the overhang and the primer sequence (bold; Supplementary Table 1).

Each replicate sample was amplified in four separate PCR reactions with the four different primer pairs (fs0, fs1, fs2, and fs3). $20 \mu \mathrm{l}$ of PCR reaction mixture was composed of $1 \times \mathrm{KAPA}$ Sybr ${ }^{\circledR}$ Fast Universal qPCR Mix (KAPA Biosystems, MA, USA), $400 \mathrm{nM}$ of each primer (Microsynth, Balgach, Switzerland), DEPC-water (Roth, Karlsruhe, Germany) and $2 \mu \mathrm{l}$ of DNA template. Low cycle amplicon PCR was performed using a Labcycler (SensoQuest, Göttingen, Germany) thermal cycler with the following program: denaturation at $95^{\circ} \mathrm{C}$ for $5 \mathrm{~min}$ followed by 10 cycles of $95^{\circ} \mathrm{C}$ for $30 \mathrm{~s}$, annealing at $55^{\circ} \mathrm{C}$ for $30 \mathrm{~s}$ and extension at $72^{\circ} \mathrm{C}$ for $30 \mathrm{~s}$. A final extension step was run at $72^{\circ} \mathrm{C}$ for $5 \mathrm{~min}$. The PCR products of each sample with the four different primer pairs ( $\mathrm{fs} 0, \mathrm{fs} 1, \mathrm{fs} 2$, and $\mathrm{fs} 3$ ) were pooled and subsequently purified with $0.8 \times$ Agencourt AMPure XP Kit (Beckman Coulter, CA, USA) following the manufacturer's instructions. Purified PCR products were resuspended in $30 \mu \mathrm{l}$ of DEPC-water.

Nextera XT Index PCR was performed in $50 \mu$ l of PCR mixture composed of $1 \times$ KAPA Sybr ${ }^{\circledR}$ Fast Universal qPCR Mix (KAPA Biosystems), $5 \mu$ l of Nextera forward (N7XX) and reverse (S5XX) indices and $15 \mu \mathrm{l}$ of previously purified PCR product.
Index PCR was performed as described above, but with 8 cycles instead of 10. PCR products were purified as described above with $1 \times$ Agencourt AMPure XP Kit (Beckman Coulter).

Purity of the index PCR products was checked with the Bioanalyzer High Sensitivity Chip (Agilent Technologies, Santa Clara, USA). Concentration of the index PCR products was determined with the Qubit ${ }^{\circledR}$ Fluorometer dsDNA HS Assay Kit and by qPCR with the KAPA Library Quantification Kit for MiSeq Illumina ${ }^{\circledR}$ (KAPA Biosystems) following manufacturer's instructions. Samples were pooled by adding $0.75 \mathrm{nM}$ of each sample to the library, which was subsequently concentrated to $4 \mathrm{nM}$ with the $1 \times$ Agencourt AMPure XP Kit (Beckman Coulter).

\section{High Throughput Amplicon Sequencing}

Paired-end $(2 \times 300 \mathrm{nt})$ high throughput sequencing of PCR amplicons of the 16S rRNA gene was performed in a single multiplexed run on an Illumina MiSeq (Illumina ${ }^{\circledR}$ Inc., San Diego, USA; software v2.4.1.3) at the GDC. A total of 4,095,381 sequences were obtained from 23 samples. The sequences of the field replicates $\mathrm{A}-\mathrm{C}$ were merged resulting in 8 samples: J0: 462,608 reads; J1: 543,977; J2: 107,085; J3: 88,383; J4: 961,545; J5: 198,260; J6: 1,108,814; J7: 624,709. All results based on HTS reported in this study are based on these 8 samples. 16S rRNA gene data processing was performed following the pipeline designed at the GDC (Supplementary Table 2). Sequences were clustered at $97 \%$ sequence similarity's level and defined as Operational taxonomic unit (OTU) with Uparse in Uchime (Edgar, 2013). Only OTUs detected more than 3 times were considered for community analysis, reducing the complexity from 637 to 539 OTUs. The sequence reads obtained in this study were deposited in the European Nucleotide Archive (ENA) with the project number PRJEB9478 (www.ebi.ac.uk/ena/data/view/PRJEB9478).

\section{Real-Time Quantitative PCR}

Quantification of 16S rRNA gene copies was performed by realtime quantitative PCR (qPCR) on an ABI 7500 system (Applied Biosystems) at the GDC. $20 \mu \mathrm{l}$ of the qPCR reaction mixture contained $1 \times$ KAPA Sybr $^{\circledR}$ Fast Universal qPCR Mix (KAPA Biosystems), $400 \mathrm{nM}$ of each primer, forward B341F_fs0 and reverse B805R_fs0 (Microsynth, Balgach, Switzerland), DEPCwater (Roth, Karlsruhe, Germany) and $1 \mu \mathrm{l}(0.2-43 \mathrm{ng} / \mu \mathrm{l})$ of DNA template per reaction. Triplicates of no-template controls, containing DEPC-treated water, were included. Thermal cycles were performed using the following program: denaturation at $95^{\circ} \mathrm{C}$ for $10 \mathrm{~min}$ followed by 40 cycles of $95^{\circ} \mathrm{C}$ for $20 \mathrm{~s}$, annealing at $55^{\circ} \mathrm{C}$ for $30 \mathrm{~s}$, and extension and acquisition at $72^{\circ} \mathrm{C}$ for $1 \mathrm{~min}$. A final extension step was run at $72^{\circ} \mathrm{C}$ for $5 \mathrm{~min}$.

As bacterial standard, dilution series of PCR products derived from DNA extracted from the control strain Methylococcus capsulatus (strain Bath; courtesy of Prof. Svenning, University of Tromsø, Norway) in a range between $2.12 \mathrm{e}^{1}$ and $2.12 \mathrm{e}^{8}$ was used. The 16S rRNA gene copy number was calculated from the standard curves, assuming that the average molecular mass of a double stranded DNA molecule is $613 \mathrm{~g} \mathrm{~mol}^{-1}$. The $16 \mathrm{~S}$ rRNA gene copy number was within the range of the standard curve for all samples. 


\section{Multivariate and Statistical Numerical Analyses}

Ordination analysis by non-metric multidimensional scaling analysis (NMDS) was performed by applying Bray-Curtis dissimilarity algorithm to the lowest total count (88,383 reads of J3) normalized community composition matrix with the 7381 OTUs (Legendre and Anderson, 1999; Anderson et al., 2011). To show differences in bacterial community structure between all field samples, the NMDS was performed using the package "phyloseq" (version 1.8.2) (McMurdie and Holmes, 2013) in the $\mathrm{R}$ program (version 3.1.2) ( $\mathrm{R}$ Core Team, 2015). Each OTU is represented by a dot and to facilitate visualization, the NMDS was split based on the taxonomic affiliation of the OTUs at phylum level. Adjusted statistical significance was calculated using one-way analysis of variance (ANOVA) and a false discovery rate correction (Benjamini and Hochberg, 1995). The values of all field replicates for particle counts, conductivity, 16S rRNA gene copies, DNA were $\log 10$-transformed $(n=2$ for J0; $n=3$ for J1-J7).

The indices of biological diversity richness, E evenness, $\mathrm{J}^{\prime}$ evenness, Shannon, Simpson, Inverse Simpson and Berger were calculated using the package "vegan" 2.3-0 (Oksanen et al., 2015) and "BiodiversityR" 2.5-3 (Kindt and Coe, 2005). No error bars are shown because diversity indices were calculated after the merging of the sequences of each field replicate. Standard deviations among field replicate might not reflect biological variability but rather artificial variability of the amplicon HTS.

\section{Phylogenetic Tree}

A phylogenetic tree containing 539 OTUs aligned with PyNAST (Caporaso et al., 2010) was built using Maximum Likelihood method and the software FastTree 2.1 (Price et al., 2010). The tree was visualized with ITOL (Letunic and Bork, 2011).

\section{Ecophysiology}

Biolog incubations were performed by inoculating $200 \mu \mathrm{l}$ of homogeneously mixed meltwater from each snow layer field replicate (triplicates for each layer) in a Biolog EcoPlate ${ }^{\mathrm{TM}}$ (BIOLOG, CA, USA). Incubation was performed at $4^{\circ} \mathrm{C}$ for 36 days. Color development was assessed twice a day by measuring the optical density (OD) of the samples at $595 \mathrm{~nm}$ with a Biotek plate reader (Bio-TeK, VT, USA). The time point of maximum Average Well Color Development (AWCD) was observed after $739 \mathrm{~h}$ (30.8 days) of incubation. AWCD for each time point was calculated according to the formula described in Lazzaro et al. (2015).

Samples J0 and J4 were sterilized by $\mathrm{CHCl}_{3}$ fumigation to test whether the increasing $\mathrm{OD}_{595}$ measured during the Biolog incubation was influenced by dust particles, by active exoenzymes or by metabolically active bacterial cells. We fumigated $7 \mathrm{ml}$ of meltwater in glass beakers as described in Blankinship et al. (2014) for 1 day. Biolog incubation was performed as described above.

\section{RESULTS}

\section{Source and Deposition of Sahara Dust Particles}

We report here a strong SDE detected by the method described in Collaud Coen et al. (2004) at the Jungfraujoch in February 2014. The winter SDE lasted $40 \mathrm{~h}$, starting on 18 February 2014 at 05:03:50 (CET) and ending on 19 February 2014 at 21:04:16 (CET). Backward trajectories indicate that south-central Algeria is the likely source region of the aerosols deposited during the SDE. Neighboring countries including Niger, Mali and Morocco (Figure 1A) may have also contributed dust particles. Uplifted SD particles were transported to the Alps without any further contact with the ground until deposition on the snow at the Jungfraujoch (Figure 1A; lower panel). Meteorological records indicate that the SD particles were covered by fresh snow 3 days after being deposited at freezing temperatures between $-17.1^{\circ} \mathrm{C}$ and $-6^{\circ} \mathrm{C}$ (Supplementary Figure $2 \mathrm{~B}$ ).

Between the February SDE and the sample collection date ( 8 June 2014), an additional SDE was detected at the Jungfraujoch starting on 21 May 2014 at 20:44:25 (CET) and lasted 22.4 h until 22 May 2014 at 19:06:38 (CET). Backward trajectories indicate that aerosols of the spring SDE likely originated from the northwestern part of the Algerian desert (Figure 1B). The SD particles of the spring SDE were deposited just before snowmelt at temperatures between $-4.4^{\circ} \mathrm{C}$ and $-0.9^{\circ} \mathrm{C}$ (Supplementary Figure 2A). Based on the negative exponent of the single scattering albedo, the winter SDE was about 6 times as intense as the spring SDE.

\section{Snow Profile and Physicochemical Parameters}

The 200-cm deep snow profile displayed four distinct snow layers (Figure 2). The distinct ochre color of the two thin bands designated as $\mathrm{J} 0$ and $\mathrm{J} 4$ at $-25 \mathrm{~cm}$ and $-150 \mathrm{~cm}$, respectively, allowed us to ascribe these deposits to potential SDEs. For simplicity, we hereafter refer to $\mathrm{J} 0$ and $\mathrm{J} 4$ as SD-layers and to all other samples (J1, J2, J3, J5, J6, and J7) as CS-layers. SDlayer $\mathrm{J} 4$ was unaffected by freeze-thaw cycles but slightly altered by snow compaction (Supplementary Figure 1B). In contrast, J0 was affected by freeze-thaw cycles in the days immediately prior to sampling, as air temperature rose above freezing during the day (Supplementary Figure 2B). On the day of sampling, the freezing point was measured at $-25 \mathrm{~cm}$, within SD-layer J0 (Supplementary Figure 1A).

Temperatures in the snow profile varied from -0.4 to $-4.9^{\circ} \mathrm{C}$ and decreased with increasing depth (Figure 3A). The temperature in layer $\mathrm{A}$ was around $-0.5^{\circ} \mathrm{C}$, between -0.7 and $-3.5^{\circ} \mathrm{C}$ in layer $\mathrm{B}$, between -3.5 and $-4.5^{\circ} \mathrm{C}$ in layer $\mathrm{C}$ and below $-4.5^{\circ} \mathrm{C}$ in layer $\mathrm{D}$. Snow density increased with increasing depth from 0.32 to $0.43 \mathrm{~g} \mathrm{~cm}^{-3}$; two deviations from this trend were found at $-30 \mathrm{~cm}$ and $-150 \mathrm{~cm}$ (Figure 3B).

The $\mathrm{pH}$ in the SD-layers was around 7.2, and significantly lower $(P<0.01)$ than that of CS-layers ( $\mathrm{pH}$ 7.4-7.6; Figure 3C). A significant difference was also observed for conductivity $(P<$ 0.001; Figure 3D): SD-layers had values between 126 and $130 \mu \mathrm{S}$ 

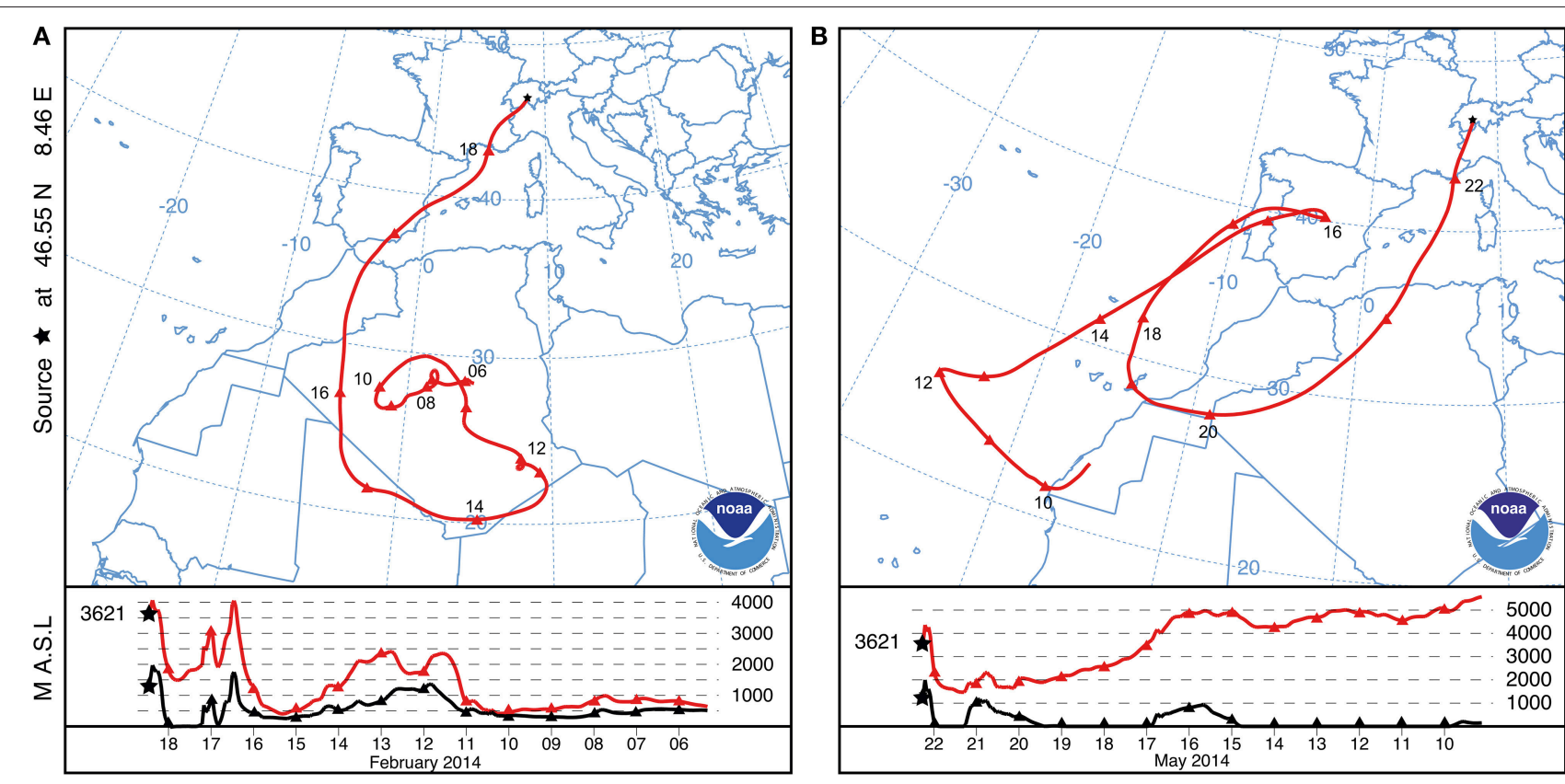

FIGURE 1 | NOAA HYSPLIT backward trajectory of air masses that reached the sampling site at Jungfraujoch (3621 m a.s.I.; black star). Only one representative trajectory is shown out of 40 and 22 trajectories for each hour of the February and May SDE length, respectively. The lower panel shows the vertical trajectory of the air masses (red line) with respect to the relief (black line). (A) One selected characteristic trajectory of the SDE in February 2014. (B) One selected characteristic trajectory of the SDE in May 2014.

$\mathrm{cm}^{-1}$, whereas the conductivity of the CS-layers ranged between 47 and $76 \mu \mathrm{S} \mathrm{cm}^{-1}$.

The dust particle concentration observed in J4 (2300 particles $\mathrm{ml}^{-1}$ snow) was two orders of magnitude greater than that of the CS-layers (3-22 particles $\mathrm{ml}^{-1}$ snow), and 9.1 times greater than that of J0 (250 particles $\mathrm{ml}^{-1}$ snow) (Figure 3E). The SDlayers were significantly enriched in dust particles compared to the CS-layers $(P<0.00001)$.

\section{Geochemical and Mineralogical Analyses}

Two out of three bedrock samples collected at Jungfraujoch were gneisses, Rock1 and Rock2, whereas Rock3 was a limestone (Supplementary Table 3), which is evidence of the geological heterogeneity of the Jungfraujoch region (Labhart, 2001). The felsic mineral particles in the gneisses exhibited a low variety of mixed-phases and could therefore be easily assigned to a typical mineral phase cluster, whereas the mineral particles of the limestone plotted outside the defined clusters of felsic minerals (Figure 4D). In contrast, the deposited SD particles contained a larger variety of mixed-phase minerals (Figures $4 \mathrm{~B}, \mathrm{C}$ ). In comparison to the CS-layers (Figure 4A), SD-layers had higher particle concentrations (Figure 3E). Most of these particles plotted between 1.5 and 1.8 on the $\mathrm{x}$-axis and $0.4-0.6$ on the $\mathrm{y}$ axis and could not be assigned to any mineral phase (box nr. 6 in Figures 4B,C). These particles represented approximately $34 \%$ of all particles in the SD-layers but only $16.6 \pm 5.6 \%$ in the CS-layers and were completely absent in the bedrocks. J0 contained more illite particles than $\mathrm{J} 4$ ( 8.7 vs. $4.4 \%$ ) but less kaolinite particles ( 0.7 vs. $2.3 \%)$. The $\mathrm{I} / \mathrm{K}$ ratio was therefore higher in J0 than in
$\mathrm{J} 4$ (6.75 vs. 1.21$)$. The $(\mathrm{Ca}+\mathrm{Mg}) / \mathrm{Fe}$ [wt.\%] ratio was similar in both SD-layers (J0: 0.41; J4: 0.39). Finally, diatoms were detected exclusively in J4 (Figure 5).

\section{Biomass and Diversity Indices}

The SD-layers contained similar average quantities of DNA per volume of meltwater (J0: $8.2 \mathrm{ng} \mathrm{ml}^{-1}$ and $\mathrm{J} 4: 11.8 \pm 10.6 \mathrm{ng}$ $\left.\mathrm{ml}^{-1}\right)$, and significantly more DNA $(P<0.001)$ than the CSlayers (0-1 ng ml${ }^{-1}$; Figure 6A). Although DNA was more abundant in J4 than in J0 by a factor of 1.4, the number of $16 \mathrm{~S}$ rRNA gene copies per ml meltwater was 10.9 times higher in J4 as compared to J0. However, despite that difference, the SDlayers contained a significantly $(P<0.001)$ higher amount of 16S rRNA gene copies (J0: $7.9 \times 10^{5}$ copies $\mathrm{ml}^{-1}$ meltwater; J4: $8.7 \times 10^{6}$ copy $\mathrm{ml}^{-1}$ meltwater) than the CS-layers (1.0-4.2 $\times 10^{5}$ copies $\mathrm{ml}^{-1}$ meltwater; Figure 6B). DNA concentration $\left(R^{2}=0.62, P<0.00001\right)$ and $16 \mathrm{~S}$ rRNA gene $\left(R^{2}=0.6\right.$, $P<0.0001)$ copies were both positively correlated with particle concentrations.

The species richness was significantly higher in the SD-layers (J0: 459 OTUs; J4: 339 OTUs; $P<0.05)$ than in the CS-layers (163-322 OTUs; Figure 6C), but no significant correlation between richness and depth was observed. Despite the greater richness of the SD-layers, a higher concentration of bacterial cells was not detected by flow cytometry (data not shown). Inverse Simpson $(P<0.01)$ and Shannon $(P<0.05)$ values were significantly higher in SD-layers (inverse Simpson: J0: 6.4, J4: 7.7; Shannon: J0: 2.5, J4: 2.4) than in the CS-layers (inverse Simpson: 1.1-4.8; Shannon: 0.2-1.9) (Figure 6D, Supplementary Figure 


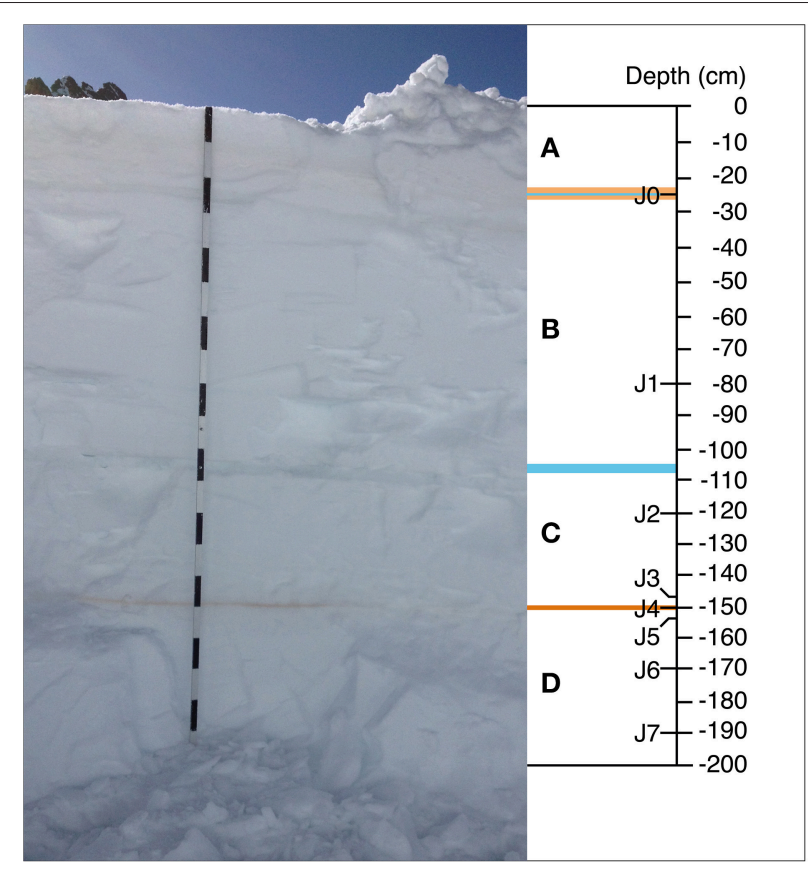

FIGURE 2 | Section of one vertical snow profile sampled at Jungfraujoch. (A-D) the observed four different snow layers. (A) $24 \mathrm{~cm}$ thick and limited at the top by the snow surface and at the bottom by a $0.3 \mathrm{~cm}$ thick ice lens (blue) located within a faint, ochre-colored $3.5-\mathrm{cm}$ thick layer that corresponded to sample J0. (B) $78.5 \mathrm{~cm}$ thick, ranging in depth from -26.5 to $-105 \mathrm{~cm}$, delimited at the bottom by a $2.5-\mathrm{cm}$ thick ice lens (blue) associated with surface exposure during a period with no snowfall in April. (C) $42.5 \mathrm{~cm}$ thick; ranging in depth from -107.5 to $-150 \mathrm{~cm}$ and delimited at the bottom by a distinct, ochre-colored layer $0.6 \mathrm{~cm}$ thick. That layer corresponded to sample $\mathrm{J} 4$. (D) $50 \mathrm{~cm}$ thick, ranging in depth from -150 to $-200 \mathrm{~cm}$. The sample J0 sample was collected in field duplicates, J1-J7 in field triplicates.

3B). However, no significant difference between in Simpson and Berger diversity could be identified between SD- and CS-layers (Supplementary Figures 3A,C). E and J' evenness decreased with depth except in J3 and 44 (Figures 3D, 6E) and was similar in the SD-layers (J0: 0.026, J4: 0.032). Despite decreasing diversity and evenness values, no significant Spearman's correlations between these indices and depth could be observed, which was mainly due to the anomalous values in $\mathrm{J} 4$.

\section{Bacterial Community Analysis}

In the NMDS, J0, and J4 clustered together and were distinct from the other samples (Figure 7). This difference is mostly explained by the axis NMDS1, which results from the presence of a few phyla in the SD-layers, including Gemmatimonadetes, Deinococcus-Thermus and certain Bacteroidetes and Chloroflexi. The phyla with the highest number of phylotypes were the Proteobacteria, Actinobacteria and Firmicutes; these phyla were equally distributed in all layers. The less well-represented phyla Acidobacteria and Cyanobacteria were more abundant in the CSlayers than in the SD-layers. The phyla Elusimicrobia, FBP, OD1, Planctomycetes and WPS-2 were each represented by a maximum of four OTUs.

\section{Bacterial Composition}

Proteobacteria was the most abundant phylum in both SD- and CS-layers (J0: 79.7\%; J4: 69.8\%; CS-layers: 73.9\%; Supplementary Figure 4; Supplementary Table 4). The SD-layers differed from the CS-layers in the composition of Proteobacteria at the class level and were dominated by Betaproteobacteria (J0: 76.2\%; J4: 36.3\%; CS-layers: 23.7\%). In fact, SD-layers contained a higher abundance of the family Comamonadaceae than the CS-layers (J0: 40.3\%; J4: 11.6\%; CS-layers: <1\%), most of which were related to the genera Variovorax, Polaromonas and Delftia. The second most abundant Betaproteobacterium was Janthinobacterium, a member of the family Oxalobaceraceae, which was highly abundant in all layers (J0: 15.9\%; J4: $24.5 \%$; CS-layers: 18.0\%). Gammaproteobacteria related to the genus Pseudomonas were particularly abundant in the CS-layers and J4 (J0: <1\%; J4: 33\%; CS-layers: 49.2\%) Alphaproteobacteria had low abundances in all samples (J0: 3.2\%; J4: <1\%; CS-layers: 1.1\%) and was mostly represented by Sphingomonas.

Bacteroidetes were highly abundant in the SD-layers but negligible in the CS-layers (J0: 6.5\%; J4: 29.2\%; CS-layers: <1\%). Both SD-layers shared a high abundance of Hymenobacter (J0: 6.4\%; J4: 9.3\%; CS-layers: <1\%), whereas Flavobacterium was highly abundant only in J4 (J0: <1\%; J4: 20.0\%; CS-layers: <1\%).

Sporulating bacteria such as Actinobacteria and Firmicutes were present in low abundances. Actinobacteria was detected in abundance only in J0 (J0: 10.4\%; J4: <1\%; CS-layers: $3.4 \%$ ) and were mostly represented by Salinibacterium and Micrococcaceae, two members of the family Microbacteriaceae. Firmicutes, mostly represented by Bacilli Staphylococcus, was detected only in the CS-layers (J0: $<1 \%$; J4: $<1 \%$; CS-layers $2.1 \%)$. Gemmatimonadetes showed low abundance in the SDlayers but were almost completely absent in the CS-layers (J0: 0.6\%, J4: 0.2\%; CS: <0.01\%). Deinococcus-Thermus was detected at a higher abundance in the SD layers than in other layers (J0: 0.2\%, J4: 0.01\%; CS: <0.01\%).

\section{Occurrence of Unique OTUs}

Considering the overall species richness of OTUs detected in the samples (total 539 OTUs), the most represented phyla were the Proteobacteria, followed by Actinobacteria, Bacteroidetes, Firmicutes, Chloroflexi, Cyanobacteria, Gemmatimonadetes, Acidobacteria, Deinococcus-Thermus, Planctomycetes, Elusimicrobia, FBP, OD1, WPS-1, and six undetermined phyla (Figure 8; Supplementary Table 5).

To identify the SDE-specific bacteria, we built a three-factor Venn diagram containing the OTUs of J0, J4, and the CS-layers (Figure 9A). 112 OTUs were specific to either J0 or J4 or were common to both. These OTUs represented $20.8 \%$ of all detected OTUs and $23.0 \%$ of the $481 \mathrm{J0}$ and J4 OTUs. Of the 112 OTUs, 26 were Bacteroidetes (40.6\% of all Bacteroidetes OTUs), 23 were Chloroflexi (43.4\%), 20 Proteobacteria (11.9\%), 16 Actinobacteria (13.7\%), 12 Gemmatimonadetes (75\%), 5 Firmicutes (9.3\%), 4 Deinococcus-Thermus (26.7\%), 3 Cyanobacteria (13.6\%), 2 Acidobacteria (13.3\%), and 1 FBP (100\%) (Figure 9B, Supplementary Table 5). At lower taxonomical levels, it is worth noting the overrepresentation of certain classes observed only in the SD-layers, such as 


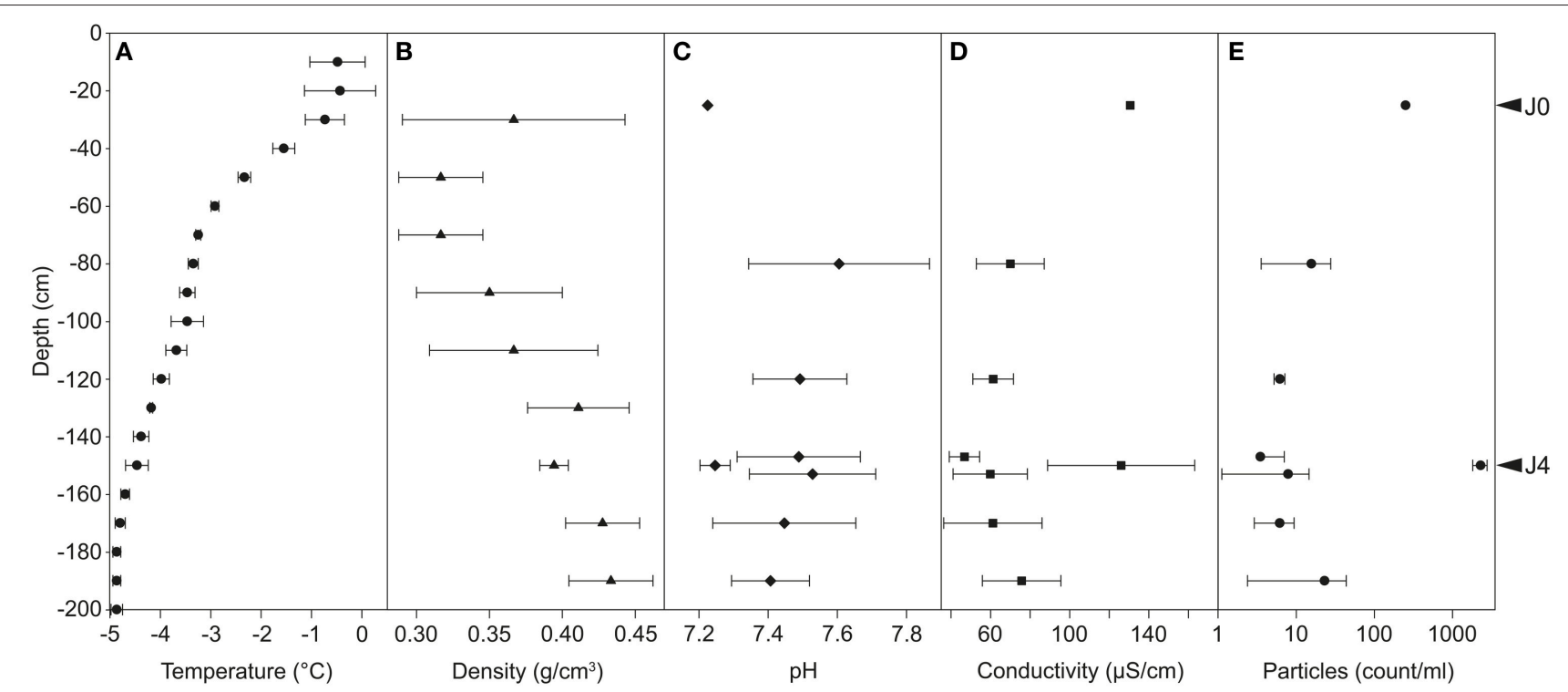

FIGURE 3 | Physicochemical properties of the snow profiles at Jungfraujoch. Temperature (A) and density (B) were measured in the field at 10- and 20-cm intervals, respectively. $\mathrm{pH}$ (C) and conductivity (D) were measured in meltwater in laboratory conditions. Particles suspended in meltwater were counted by flow cytometry (E; common Log scale). Error bars represent only positive values of standard deviation.

the members of the phylum Gemmatimonadetes: Gemm-1 (100\%), Gemm-3 (66.7\%) and Gemmatimonadetes (75\%), the deltaproteobacterium Myxococcales (75\%), Deinococci (26,7\%), the acidobacterium Chloracidobacteria (40\%), the actinobacterium Nitriliruptoria (100\%) and Thermoleophilia (40\%), the bacteroidetes Cytophagia (42.2\%) and Saprospirae (66.7\%), Chloroflexi (58.8\%), Thermobacula (66.7\%), TK10 (100\%), and an unknown class of FBP (100\%) (Figure 9C).

\section{Ecophysiology}

We analyzed the metabolic rates of all samples on different carbon substrates. Average Well Color Development of $\mathrm{OD}_{(595)}$ (AWCD) began to increase significantly in most samples after $120 \mathrm{~h}$ of incubation at $4^{\circ} \mathrm{C}$ (Figure 10). The AWCD increased constantly until hour 432 (day 18) of incubation, at which point most samples reached a plateau. The strongest activity was observed in J4, which reached an AWCD value of 0.72 after $739 \mathrm{~h}$ (day 31) and had an AWCD significantly higher than the other samples $(P<0.05)$. AWCD in J0, J1, J2, J5, and J6 achieved steady state values between 0.37 and 0.44 after $739 \mathrm{~h}$. Samples $\mathrm{J} 3$ and $\mathrm{J} 7$ showed lower metabolic activity than the others, with AWCD values of 0.21 and 0.10 , respectively (Figure 10). Negative control with $\mathrm{CHCl}_{3}$-fumigated samples showed no activity in all samples (data not shown).

The polymers Tween 40 and 80 showed a strong increase from the start of incubation and plateaued at high values in all samples (Figure 11). The polymers $\alpha$-Cyclodextrin and Glycogen were metabolized only in J4 and J5. Of the ten carbohydrate substrates tested, D-Mannitol was generally metabolized the best, followed by i-Erythritol, N-Acetyl-D-Glucosamine and D-Xylose.

$D$-cellobiose and $\alpha$-d-lactose were strongly metabolized by bacteria in both SD-layers, but only slightly in the CS-layers.
The consumption of D-Galactonic Acid $\gamma$-Lactose was observed only in J4, and D-Galacturonic Acid was the only carboxylic acid metabolized above AWCD in all samples. The utilization of Pyruvic Acid Methyl Ester, D-Glucosaminic Acid and Itaconic Acid was generally low, but highest in J4. The amino acids LAsparagine and L-Arginine showed the strongest consumption rates compared to all other carbon sources, with the highest value in the SD-layers.

\section{DISCUSSION}

\section{Deposition and Trajectory}

Generally, SD emission is low in winter and SDEs that travel toward Europe are rare (Shao et al., 2011). Only 29\% of all SDEs last longer than $24 \mathrm{~h}$; evidence of such events is most commonly found at the Jungfraujoch between March and June and between October and November (Collaud Coen et al., 2004; Flentje et al., 2015). The winter SDE of February 2014 was therefore exceptional in terms of both season and duration. Since the Jungfraujoch is situated above the planetary boundary layer in winter, aerosols are not exposed to anthropogenic contamination after their deposition on the snow. However, it is impossible to exclude anthropogenic contamination during the transport. Moreover, the SD particles from the winter SDE were deposited as a thin layer and covered by fresh snow 3 days after the SDE. The SD-layer was therefore preserved under freezing conditions until the sampling. Based on these observations, we could link the well-preserved J4 SD-layer to the winter SDE of February 2014. The less well-defined SD-layer J0, affected by freeze-thaw cycles, corresponded to the spring SDE deposited in May 2014.

Backward trajectories were used to project the main potential source region of the SDEs (Figure 1). The trajectory analysis 


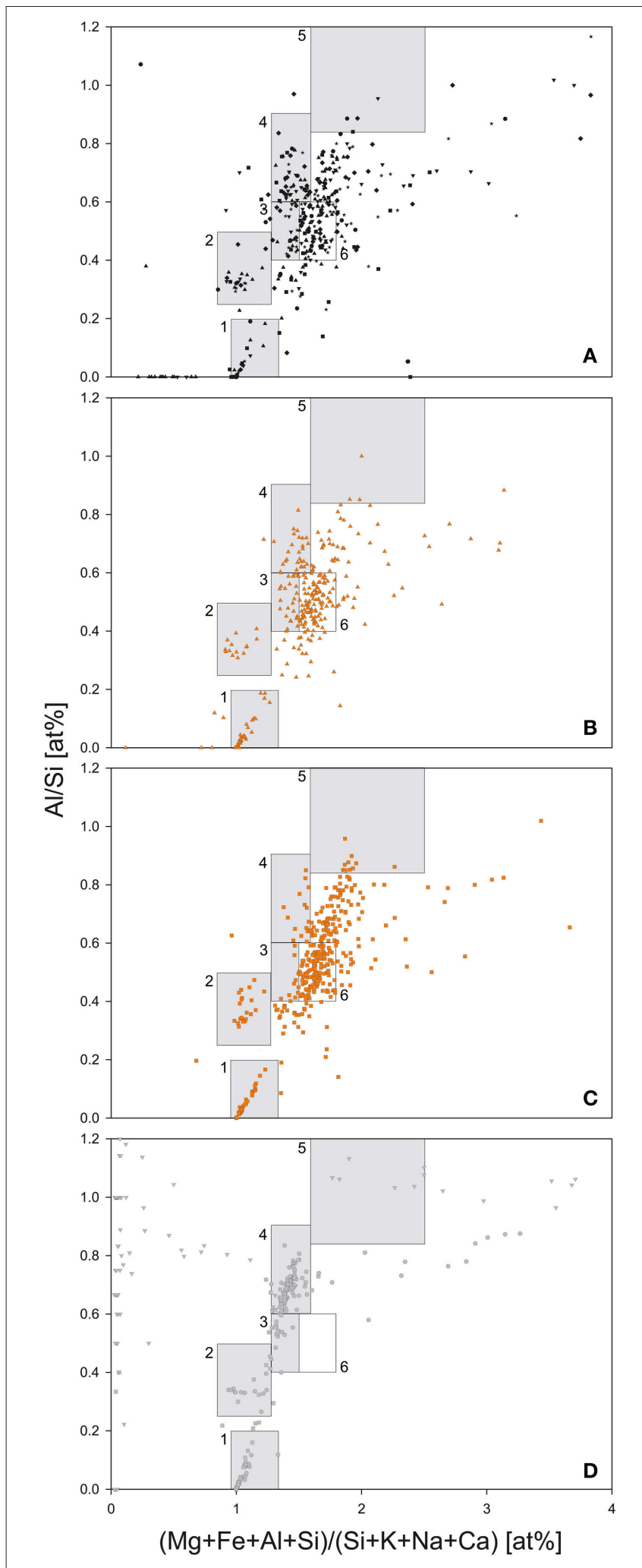

FIGURE 4 | Geochemical analysis of dust particles and bedrock samples by SEM-EDX. (A) CS-layers (J1, J2, J3, J5, J6, and J7). (B) SD-layer J0. (C) SD-layer J4. (D) Bedrock samples Rock1 (circles),

(Continued)

\section{FIGURE 4 | Continued}

Rock2 (squares), and Rock3 (triangles). Boxes represent potential mineral phases: (1) quartz; (2) feldspar; (3) montmorillonite; (4) muscovite and illite; (5) kaolinite; (6) Range of particles enriched in SD-layers J0 and J4 as compared to clean snow and bedrock samples.

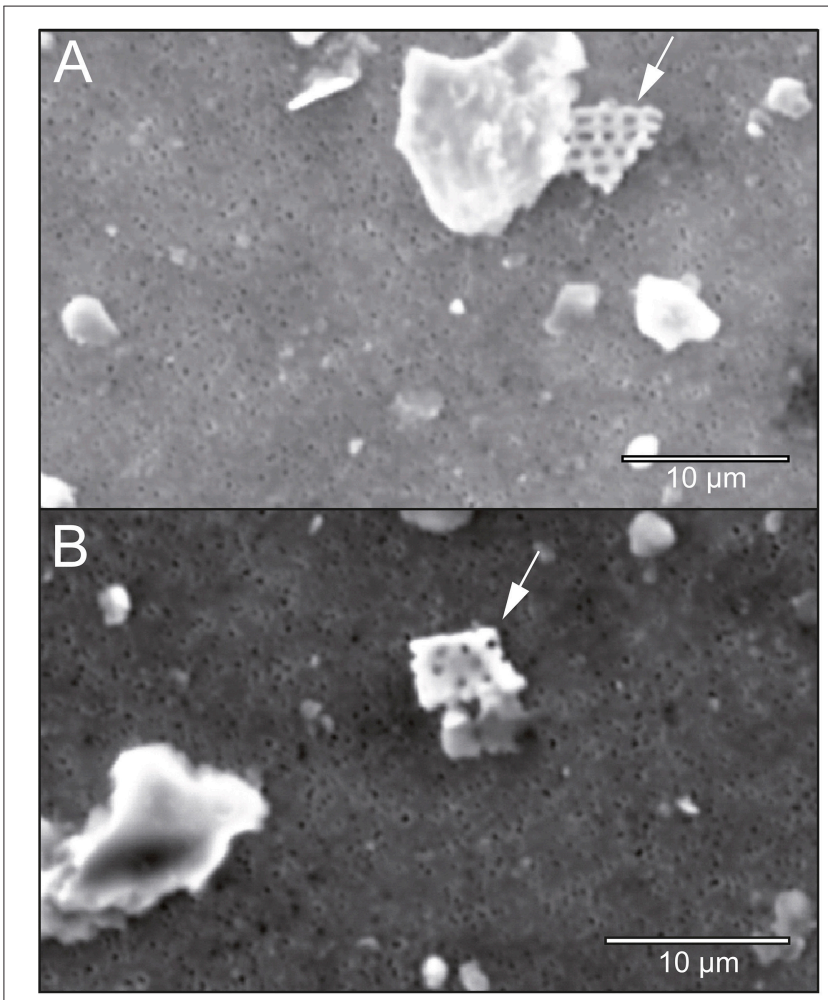

FIGURE 5 | Diatom fragments (arrow) detected on two different field replicates of $\mathbf{J 4}$ under the SEM. A diatom fragment in sample J4A (A) and J4B (B).

suggests that the winter SDE (J4) originated in central-southern Algeria and, to a lesser extent, in the neighboring countries. The SD particles uplifted in the desert remained in the atmosphere until their deposition on the Jungfraujoch. The trajectory of the spring SDE (J0) indicates that its potential source region was northwestern Algeria. This is in agreement with the observation of Collaud Coen et al. (2004) that $90 \%$ of the SDEs detected in Switzerland potentially originate in Algeria, although the source can vary slightly between seasons. Although the NOAA HYSPLIT trajectories represent interpretations from well-established models for atmospheric processes, the results of the model have to be treated with caution as they give only approximate information of the dust origin.

\section{Geochemical and Mineralogical Characteristics}

The SD-layers were significantly enriched in dust particles as compared to the CS-layers, and particularly enriched 


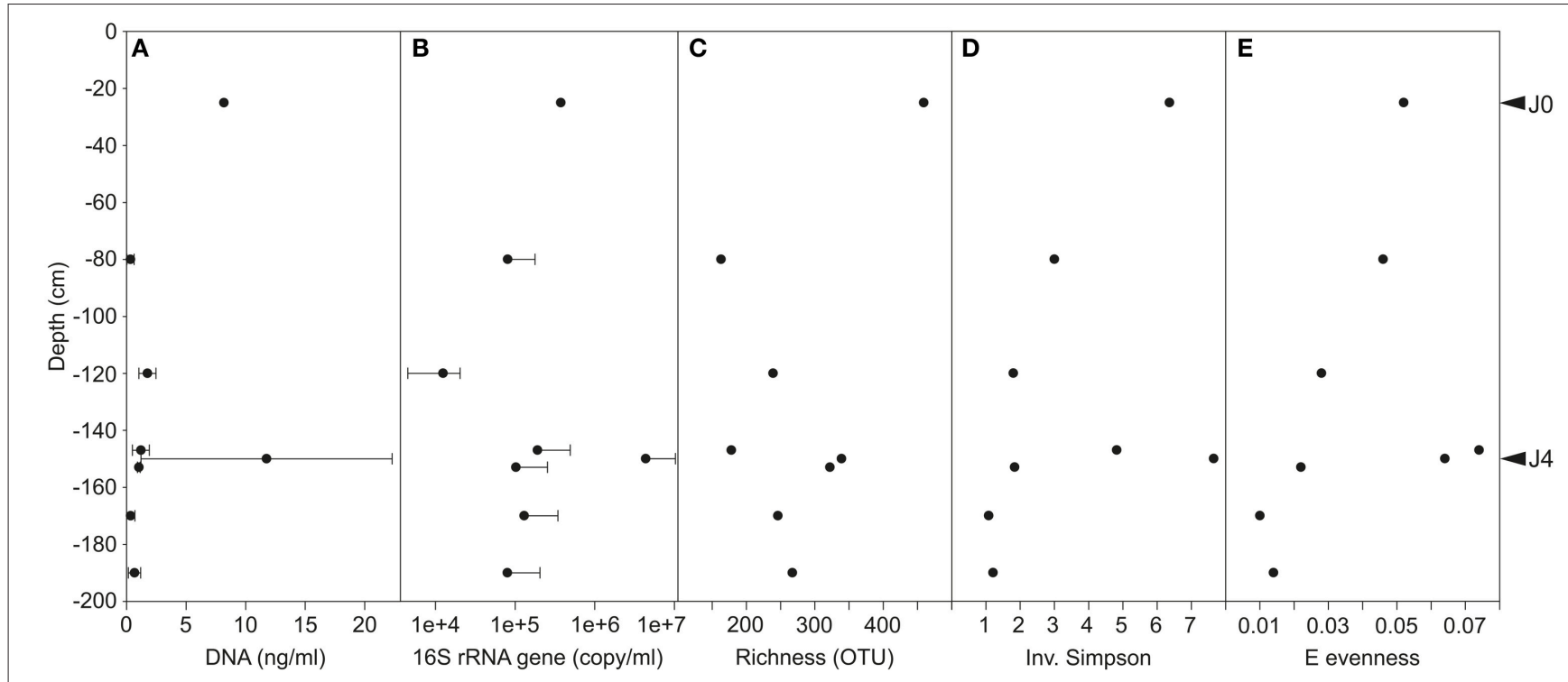

FIGURE 6 | (A) DNA concentration. Variability was high in J4 where DNA concentration ranged between 4.5 and $23.8 \mathrm{ng} \mathrm{ml}^{-1}$ meltwater. (B) $16 \mathrm{~S}$ rRNA gene copies per $\mathrm{ml}$ of meltwater (common Log Scale). Error bars represent only positive values of standard deviation. Diversity indices of Richness (C), Inverse Simpson (D), and E evenness (E) on bacterial communities of merged field replicates, therefore no standard deviations are shown.

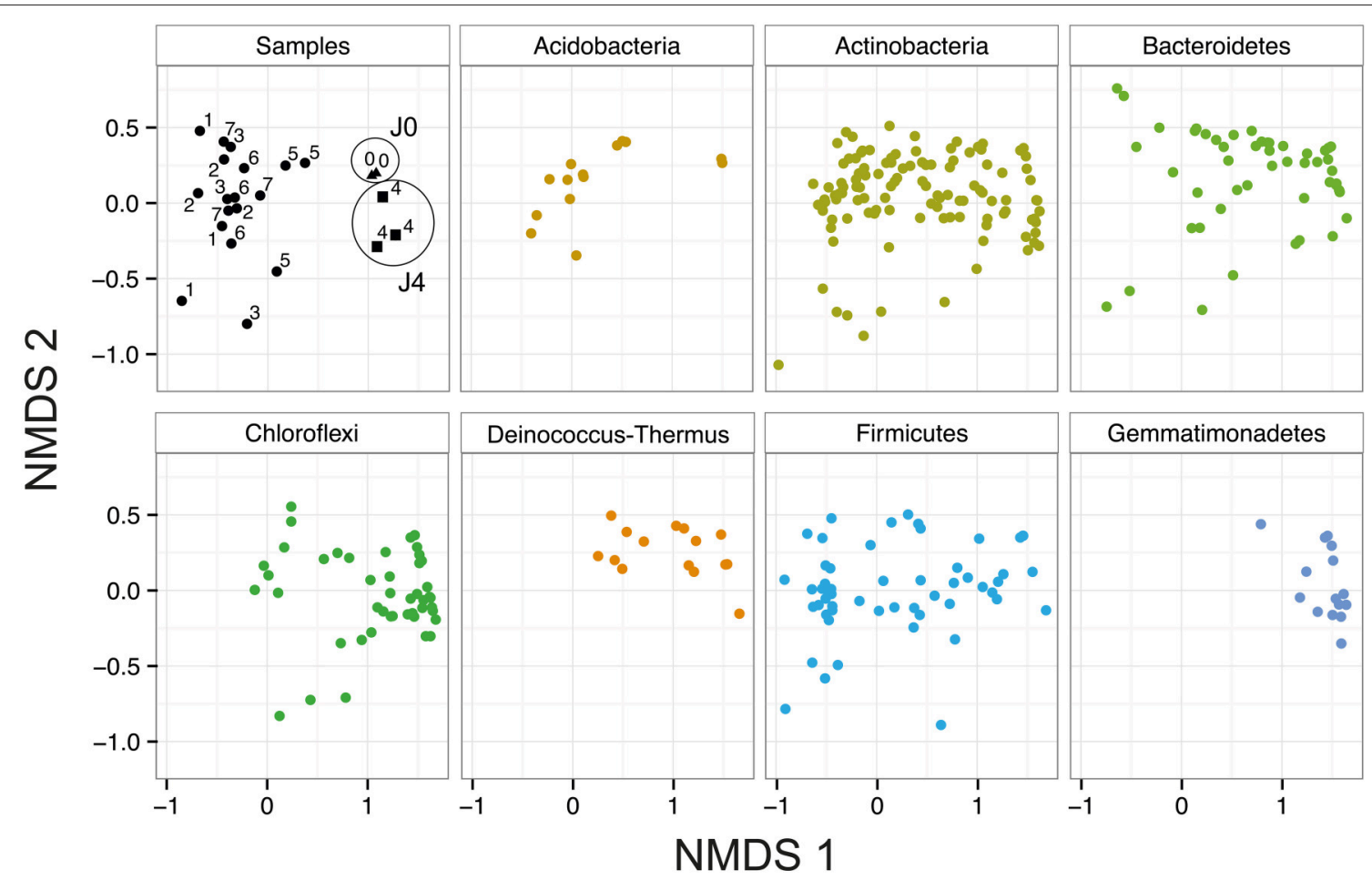

FIGURE 7 | Bacterial community composition in snow at Jungfraujoch. NMDS analysis of the bacterial communities based on Bray-Curtis dissimilarity of all 23 field sample replicates (Two factor stress value $=0.14$ ). Samples JO (triangles) and J4 (squares) are highlighted with circles.

in undefined mixed-phase particles. These mixed-phase particles were absent in the surrounding bedrock, indicating an allochthonous origin of those particles. The average bulk composition of SD particles was dominated by $\mathrm{SiO}_{2}$ and
$\mathrm{Al}_{2} \mathrm{O}_{3}$ followed by other commonly reported oxides (Collaud Coen et al., 2004; Krueger et al., 2004; Goudie and Middleton, 2006). Although the northwestern Saharan Atlas region is characterized by carbonates (Moreno et al., 2006; Sodemann 


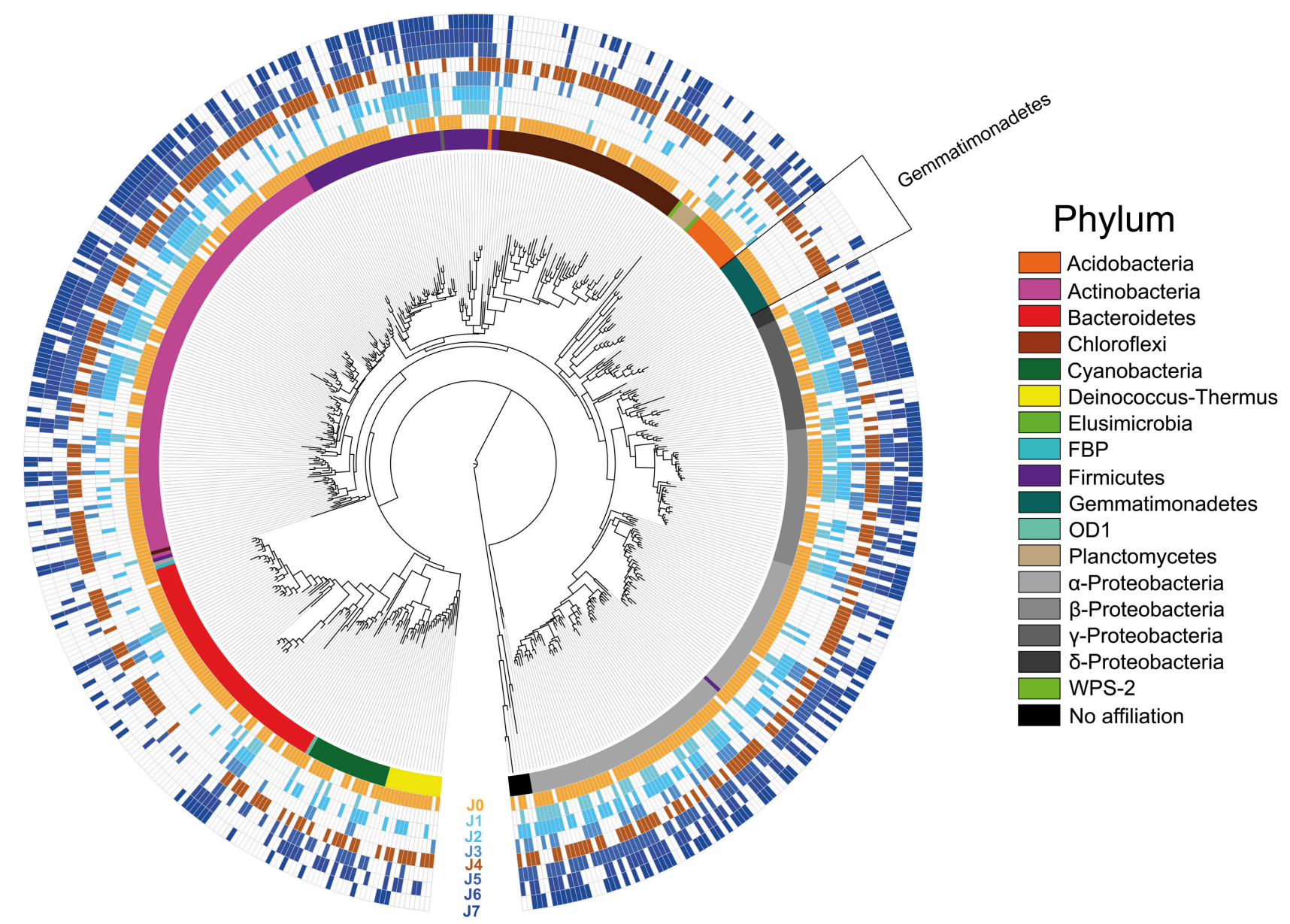

FIGURE 8 | Most Likelihood phylogenetic tree with presence/absence of all OTUs. Empty fields portray absence, whereas colored fields portray presence of an OTU. The snow samples collected at different depths are presented with increasing dark blue color. The SD-layers are presented in light brown (JO) and dark brown (J4). Colors of the inner ring correspond to the phyla in the legend.

et al., 2006), no enrichment of $\mathrm{CaO}$ was observed in $\mathrm{J} 0$, which originated from that region according to the backward trajectory.

SD particles are generally dominated by silica (quartz and diatoms), clay minerals (illite, kaolinite, montmorillonite or palygorskite), feldspars, carbonates (calcite, dolomite) and evaporitic minerals (gypsum, halite) (Evans et al., 2004; Moreno et al., 2006) and are of similar composition to SD aerosols collected at the Jungfraujoch (Schwikowski et al., 1995; Collaud Coen et al., 2004). The dissolution of evaporitic minerals could explain the significantly higher conductivity, lower $\mathrm{pH}$ and lower snow density observed in the SD-layers as compared to the CS-layers.

The illite/kaolinite $(\mathrm{I} / \mathrm{K})$ ratio has been proposed as an effective mineralogical signature for discriminating between SD source regions (Caquineau et al., 2002; Scheuvens et al., 2013). Dust from the western and northern Sahara exhibit the highest amounts of illite, whereas kaolinite dominates soils of the southern Sahara and Sahel (Caquineau et al., 2002). The I/K ratios observed in the SD-layers support the hypothesis that J0 originated in northwestern Algeria and J4 in central-southern Algeria.

Diatoms were detected only in J4. This suggests that the dust particles in J4 originated further south than those in J0. In fact, detrital diatoms originate from the Bodélé Depression, which was exposed to the wind after the retreat of the MegaLake Chad (Romero et al., 1999). Together, clay particles and diatom fragments can form armored clay-diatom agglomerations that offer bacteria dwelling spaces protected from UV radiation (Chappell et al., 2008; Favet et al., 2013).

Despite the importance of the mineralogical signature of the source region, the long-range transport of aerosols inevitably leads to fractionation processes that alter the size and mineralogical composition of the aerosol particles during their transport to the Alps (Claquin et al., 1999; Moreno et al., 2006). Fractionation processes and mixing of dust particles during transport further hamper a unequivocal identification of the source region based on the geochemical or mineralogical composition of the aerosols (Sodemann et al., 2006). In addition, the mineralogical signature of aerosols reaching the Jungfraujoch 
A

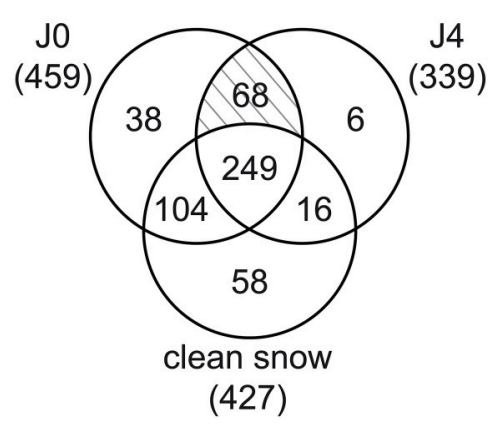

B

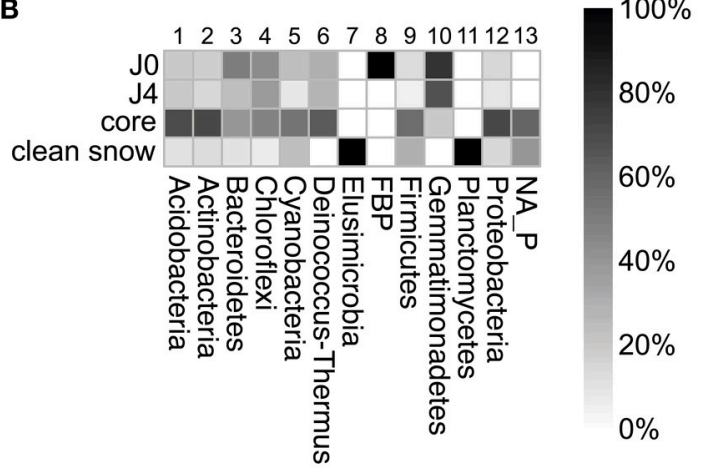

C

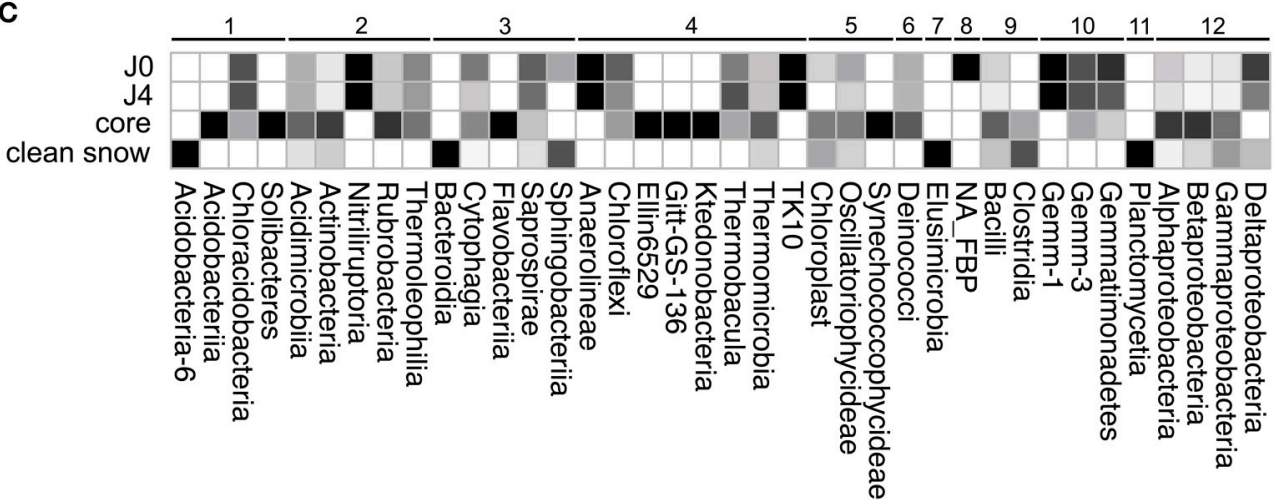

FIGURE 9 | (A) Venn diagram visualizing sections with numbers of unique and shared OTUs between SD-layers (J0, J4) and the CS-layers (J1, J2, J3, J5, J6, J7). In brackets, total OTUs for each section. Of a total of 539 OTUs, 249 composed the core community. 38 OTUs were unique for J0, 6 for J4 and 58 for the CS-layers. The shaded section represents shared OTUs between JO and J4 (68). Relative distribution of unique OTUs in the different samples at phylum (B) and class level (C). For core and CS-layers, a total of 249 and 58 OTUs were considered, respectively. For J0 and J4, the 68 shared OTUs were considered unique to both and included in the analysis, resulting in 106 OTUs for JO $(38+68)$ and 74 OTUs for J4 (6 + 68). Assigned phyla are numbered 1-12; unassigned phyla are labeled NA_P.

can vary substantially from SDE to SDE depending on the season (Sodemann et al., 2006).

\section{Microbiology}

As expected, bacterial richness and concentration, in terms of 16S rRNA gene copy per ml snowmelt, were higher in the SDlayers as compared to the CS-layers. Bacterial concentration was positively correlated with the higher dust concentration, which is in agreement with previous studies (Segawa et al., 2005). All diversity indices and evenness presented higher values in the SDlayers as compared to the CS-layers with significant differences for the Inverse Simpson and Shannon indices. The Shannon diversity index value of the SD-layers at Jungfraujoch was similar to that observed in atmospheric SD collected in Spain (Sánchez De La Campa et al., 2013), which corresponds to the lower limit of diversity commonly observed in soils (Fahlgren et al., 2010).

Interestingly, the ratio of DNA quantity to $16 \mathrm{~S}$ rRNA gene copy was higher in J0 than in J4. This may be due to a stronger presence of biological particles other than bacteria in J0, such as eukaryotes (e.g., fungi, protists, pollen). Pollen in particular is more abundant in spring, the season in which J0 was deposited. In winter, the season in which $\mathrm{J} 4$ was deposited, decaying cellular matter prevails (Jaenicke, 2005; Be et al., 2015).

\section{Common Airborne Bacteria and Pathogens}

The gram-negative Proteobacteria accounted for $70-80 \%$ of the bacterial community, a value similar to that found for aerosols from the Sahara Desert collected in Spain (Sánchez De La Campa et al., 2013; Barberán et al., 2014). However, only a few genera were dominant in the CS-layers and SD-layers. Both SD-layers contained high abundances of Betaproteobacteria Oxalobacteriaceae and Comamonadaceae, in agreement with observations of SD deposited on snow in the Central Pyrenees (Spain) (Hervas et al., 2009; Hervas and Casamayor, 2009).

The psychrophilic Janthinobacterium was present in varying abundances throughout the snowpack, confirming it as a regular member of the airborne bacterial community (Fahlgren et al., 2010). In fact, it was also found in cold environments such as snow (Chuvochina et al., 2011a), glaciers (Kim et al., 2012), alpine lakes (Peter et al., 2014) and attached to granitic rock particles in soils of the Damma glacier forefield (Switzerland) (Frey et al., 2010). Janthinobacterium produces the indigopurple pigment violacein (Pantanella et al., 2007), which is an antifungal metabolite against amphibian skin pathogens and is enhanced by the carbohydrate mannitol (Brucker et al., 2008). Previous studies have shown that mannitol is suitable as chemical tracer for fungal spores in atmospheric aerosols 


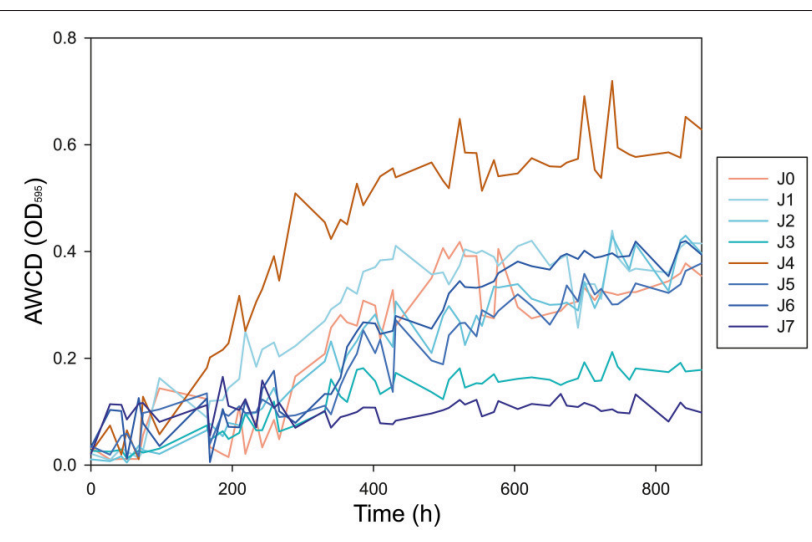

FIGURE 10 | Increase of the AWCD OD ${ }_{(595)}$ during incubation over $\mathbf{8 6 5} \mathrm{h}$ (36 days) at $4^{\circ} \mathbf{C}$. Peak metabolic activity was observed after $739 \mathrm{~h}$ (31 days) of incubation.

(Elbert et al., 2007). All of our samples showed strong metabolic activity when combined with D-mannitol, most notably SDlayer J4. Janthinobacterium also produces weathering-associated compounds such as oxalic acids and cyanide, which dissolve granite and lead to a reduction in the $\mathrm{pH}$ of the soil (Frey et al., 2010). Similar granite dissolution activity has been observed for the psychrotrophic genera Variovorax and Polaromonas (Frey et al., 2010), members of the family Comamonadaceae, which were detected in significant abundances exclusively in the SDlayers.

Pseudomonas, which was the most abundant gammaproteobacterium in the CS-layers and J4, has been shown to be a persistent member of the airborne community throughout the year (Fahlgren et al., 2010), and to be involved in cloud condensation processes (Amato et al., 2007a) and ice nucleation at temperatures close to $0^{\circ} \mathrm{C}$ (Möhler et al., 2007; Bowers et al., 2009).

Pathogens such as Neisseria meningitidis, Streptococcus pneumonia and Haemophilus influenzae are present in the "meningitis belt" of sub-Saharan Africa and known to cause meningitis. In our study, six OTUs potentially belonging to these pathogens were detected in all samples, although in very low abundances. These include two members of the family Neisseriaceae, one member of an unknown genus and one Neisseria; three members of the genus Streptococcus, one member belonging to the species infantis, and one Haemophilus parainfluenzae.

\section{Bacteria Specific to Saharan Dust}

We observed strong similarities between the bacterial community structures of the J0 and J4 SD-layers. The genera Hymenobacter (Bacteroidetes) and Comamonodaceae (Betaproteobacteria) were exclusively present in considerable abundances in the SDlayers. Other phylotypes adapted to harsh conditions, including Gemmatimonadetes, Deinococcus-Thermus, Chloroflexi and the deltaproteobacterium Myxococcales, were also found mostly in the SD-layers. Other phylotypes that were particularly abundant in the SD-layers, such as the two Bacteroidetes families
Flavobacteraceae and Cytophagaceae, were also detected in the CS-layers.

Gemmatimonadetes and Chloroflexi have been found in air masses passing over the Sahara Desert, but are absent in air masses passing over Southern Europe (Katra et al., 2014). Gemmatimonadetes have been observed in nearly all soil types (Fierer et al., 2012), but are predominant in soils from hyperarid environments with very low biomass, such as the Atacama Desert (Drees et al., 2006; Crits-Christoph et al., 2013), the Sahara Desert (Favet et al., 2013), the Tatouine Desert (Chanal et al., 2006) and McKelvey Valley (Antarctica) (Pointing et al., 2010). In fact, their presence is inversely correlated to soil moisture (Debruyn et al., 2011), indicating a tolerance for desiccation and oligotrophic conditions related to very slow cell growth (Zhang, 2003). Gemmatimonadetes have recently been found to be dominant in soils of recently deglaciated and unvegetated alpine glacier forefields (Bajerski and Wagner, 2013; Rime et al., 2015). These bacteria may originate in the Sahara Desert and be transported to the Alps following SDEs, where they find suitable environments to proliferate. Rare orange pigments (carotenoids) that function as antioxidants may help Gemmatimonadetes protect themselves against DNA damage caused by UV radiation (Tong and Lighthart, 1997; Hanada and Sekiguchi, 2014).

The Gram negative genus Deinococcus also showed a higher species richness in the SD-layers compared to the CS-layers. Deinococcus spp. are pink to red pigmented bacteria that are adapted to desiccation and radiation (De Groot et al., 2005; Callegan et al., 2008). They have been isolated from a wide range of arid environments including Antarctica (Hirsch et al., 2004) the Gobi Desert (Yuan et al., 2009), the Sonoran Desert (Rainey et al., 2005), the Sahara Desert (De Groot et al., 2005; Favet et al., 2013) and the Tataouine Desert (Chanal et al., 2006), as well as from alpine soils (Callegan et al., 2008). Deinococcus have been reported in various studies of aerosols associated with bacteria originating from the Gobi Desert (Jeon et al., 2011; Yamaguchi et al., 2014) and from the Sahara Desert (Chuvochina et al., 2011a). Therefore, both Gemmatimonadetes and Deinococcus-Thermus could be considered bio-indicators for SDEs.

The two Bacteroidetes families Cytophagaceae and Flavobacteriaceae are also abundant in the SD-layers and have been found in soils from the Sahara Desert in Chad (Favet et al., 2013) and Tunisia (Chuvochina et al., 2011b). In fact, Bacteroidetes prefer desert to non-desert soils (Fierer et al., 2012). Moreover, Bacteroidetes were also highly abundant in aerosols collected over Japan (Yamaguchi et al., 2014) and over eastern Australia (De Deckker et al., 2014). Bacteroidetes adhere preferentially to smaller particle sizes of Saharan aerosols (Polymenakou et al., 2008), which might contribute to their long-distance propagation. The most abundant phylotypes detected in the SD-layers were the pigmented and psychrotolerant Hymenobacter (Cytophagaceae) and Flavobacterium. Hymenobacter (Flavobacteraceae) was also detected in snow from the Guoqu and Zadang glaciers on the Tibetan Plateau covered with dust from Chinese deserts (Liu et al., 2009), in SD-bearing snow on Mont Blanc 


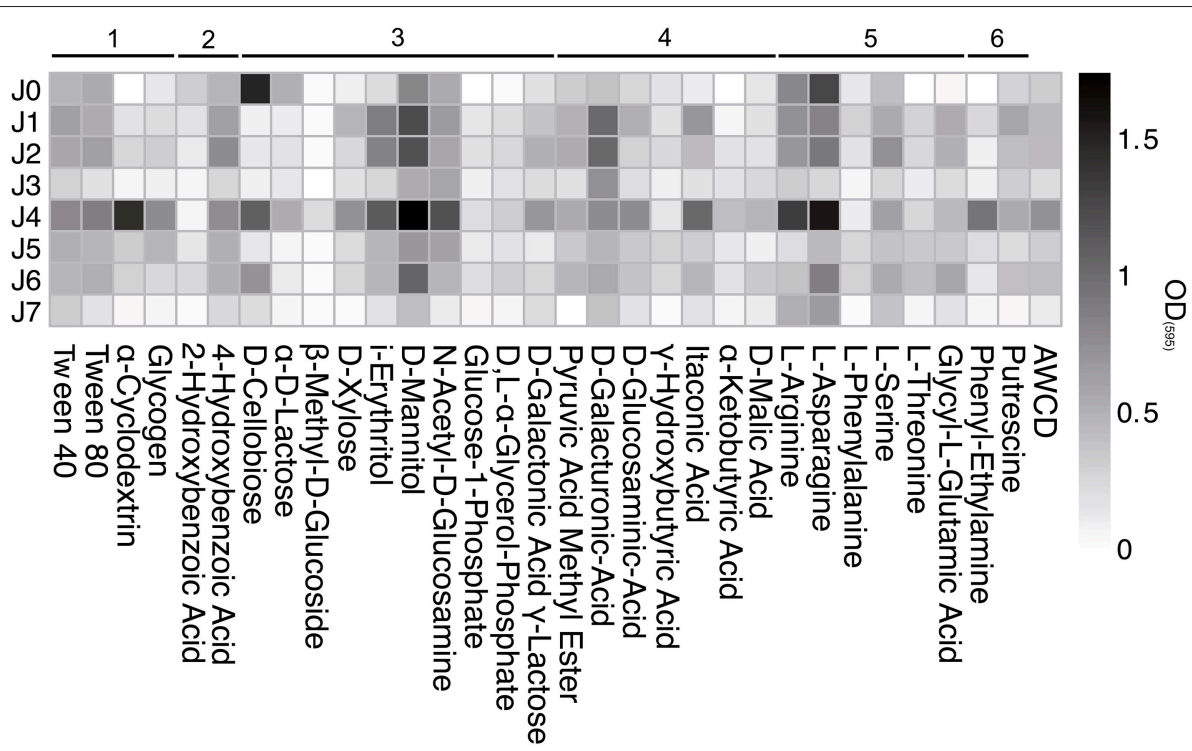

FIGURE 11 | Biolog EcoPlate ${ }^{\mathrm{TM}}$ after $\mathbf{7 3 9} \mathrm{h}$ (31 days) at $4^{\circ} \mathrm{C}$. Metabolization assay of different substrates: 1 , polymers; 2 , phenolic compounds; 3 , carbohydrates; 4, carboxylic acids; 5, amino acids; 6, amines. AWCD, Average Well Color Development of $\mathrm{OD}_{(595)}$.

(Chuvochina et al., 2011b), from desert soil in Chad (Favet et al., 2013) and over the Caribbean during a SDE (Griffin et al., 2003).

\section{Survival of Airborne Bacteria}

There is solid evidence in the literature that at least a fraction of airborne microorganism is viable (Deleon-Rodriguez et al., 2013). Based on microscopy observations, $60-100 \%$ of the bacteria appeared viable in samples from the upper troposphere (Deleon-Rodriguez et al., 2013), and were metabolically active in clouds (Hill et al., 2007). However, microscopy-based values might be overestimated if inorganic particles are stained and erroneously counted as cells (Deleon-Rodriguez et al., 2013). Moreover, limitations of traditional culture-based techniques prevent researchers from precisely assessing viability of airborne bacteria (Amato et al., 2015; Behzad et al., 2015). Biolog ${ }^{\circledR}$ incubations are partially also subject to these limitations although they are advanced cultivation-based techniques that permit the detection of metabolic activity using various carbon substrates.

Using Biolog ${ }^{\circledR}$ incubations, we were able to quantify the mean metabolic activity of the bacterial communities in each snow layer and to hence determine their viability. Bacterial communities taken from the SD-layers showed no lag phase in the Biolog ${ }^{\circledR}$ incubations suggesting that the bacteria were viable (Figure 10).

Previous studies have shown that specific airborne bacteria metabolize certain carbon substrates such as glucose (Dimmick et al., 1975) and carboxylic acids (i.e., formate, acetate, succinate, and lactate) (Amato et al., 2005). In this study, metabolic activity was higher on substrates such as the sugar L-mannitol and the amino acid L-asparagine. Although bacterial activity was higher in certain substrates than in others, it was not possible to relate individual species of airborne bacteria to specific carbon substrates.

\section{CONCLUSIONS}

Airborne bacteria are exposed to harsh conditions during transport in the upper troposphere, including desiccation stress, UV radiation, low temperatures and oligotrophic conditions. Bacteria possessing adaptive strategies (i.e., sporulation and pigmentation) were expected to be highly abundant in the SDlayers at the Jungfraujoch. In contrast to the findings of other studies (Polymenakou et al., 2008; Chuvochina et al., 2011a), however, we observed neither higher species richness nor higher abundances of sporulating bacteria in the SD-layers as compared to the CS-layers, which is in agreement with Barberán et al. (2014). Instead, we found a higher species richness of pigmentproducing bacteria that are adapted to cope with UV radiation and desiccation stress such as Gemmatimonadetes, DeinococcusThermus, Chloroflexi, and Deltaproteobacteria Myxococcales.

\section{AUTHOR CONTRIBUTIONS}

MM, AL, and JZ designed the study and did the fieldwork. MM performed the experiments, analyzed the data and wrote the study. AL and JZ contributed to the writing.

\section{ACKNOWLEDGMENTS}

We thank Christian Almer for his precious help in preparing the snow profile and Simrita Cheema for her help in the field. We acknowledge Lukas Martin and Eric Reusser (Institute of Geochemistry and Petrology, ETH Zurich) for their help during the SEM-EDX analyses. We are deeply grateful to Alessandro Franchini and Mario Meier for the many fruitful discussions and valuable suggestions. Special thanks to Erin $\mathrm{H}$. Gleeson (SciencEdit.CH) for proofreading the manuscript. We 
thank Nicolas Bukowiecki (Paul Scherrer Institute PSI) for the nephelotmeter data. High throughput sequencing with MiSeq Illumina ${ }^{\circledR}$ and qPCR were performed at the Genetic Diversity Center (GDC) of the ETH Zurich, Switzerland. This study was funded by the ETH Zurich.

\section{SUPPLEMENTARY MATERIAL}

The Supplementary Material for this article can be found online at: http://journal.frontiersin.org/article/10.3389/fmicb. 2015.01454

\section{REFERENCES}

Amato, P., Joly, M., Schaupp, C., Attard, E., Möhler, O., Morris, C. E., et al. (2015). Survival and ice nucleation activity of bacteria as aerosols in a cloud simulation chamber. Atmos. Chem. Phys. 15, 6455-6465. doi: 10.5194/acp-15-6455-2015

Amato, P., Menager, M., Sancelme, M., Laj, P., Mailhot, G., and Delort, A. M. (2005). Microbial population in cloud water at the Puy de Dome: implications for the chemistry of clouds. Atmos. Environ. 39, 4143-4153. doi: 10.1016/j.atmosenv.2005.04.002

Amato, P., Parazols, M., Sancelme, M., Laj, P., Mailhot, G., and Delort, A. M. (2007a). Microorganisms isolated from the water phase of tropospheric clouds at the Puy de Dome: major groups and growth abilities at low temperatures. FEMS Microbiol. Ecol. 59, 242-254. doi: 10.1111/j.1574-6941.2006.00199.x

Amato, P., Parazols, M., Sancelme, M., Mailhot, G., Laj, P., and Delort, A.M. (2007b). An important oceanic source of micro-organisms for cloud water at the Puy de Dôme (France). Atmos. Environ. 41, 8253-8263. doi: 10.1016/j.atmosenv.2007.06.022

Anderson, M. J., Crist, T. O., Chase, J. M., Vellend, M., Inouye, B. D., Freestone, A. L., et al. (2011). Navigating the multiple meanings of beta diversity: a roadmap for the practicing ecologist. Ecol. Lett. 14, 19-28. doi: 10.1111/j.14610248.2010.01552.x

Bajerski, F., and Wagner, D. (2013). Bacterial succession in Antarctic soils of two glacier forefields on Larsemann Hills, East Antarctica. FEMS Microbiol. Ecol. 85, 128-142. doi: 10.1111/1574-6941.12105

Barberán, A., Henley, J., Fierer, N., and Casamayor, E. O. (2014). Structure, inter-annual recurrence, and global-scale connectivity of airborne microbial communities. Sci. Total Environ. 487, 187-195. doi: 10.1016/j.scitotenv.2014.04.030

Barton, A. D., Dutkiewicz, S., Flierl, G., Bragg, J., and Follows, M. J. (2010). Patterns of diversity in marine phytoplankton. Science 327, 1509-1511. doi: 10.1126/science. 1184961

Be, N. A., Thissen, J. B., Fofanov, V. Y., Allen, J. E., Rojas, M., Golovko, G., et al. (2015). Metagenomic analysis of the airborne environment in urban spaces. Microb. Ecol. 69, 346-355. doi: 10.1007/s00248-014-0517-z

Behzad, H., Gojobori, T., and Mineta, K. (2015). Challenges and opportunities of airborne metagenomics. Genome Biol. Evol. 7, 1216-1226. doi: 10.1093/gbe/evv064

Benjamini, Y., and Hochberg, Y. (1995). Controlling the false discovery rate - a practical and powerful approach to multiple testing. J. R. Stat. Soc. B Methodol. 57, 289-300.

Blankinship, J. C., Becerra, C. A., Schaeffer, S. M., and Schimel, J. P. (2014). Separating cellular metabolism from exoenzyme activity in soil organic matter decomposition. Soil Biol. Biochem. 71, 68-75. doi: 10.1016/j.soilbio.2014.01.010

Bowers, R. M., Lauber, C. L., Wiedinmyer, C., Hamady, M., Hallar, A. G., Fall, R., et al. (2009). Characterization of airborne microbial communities at a highelevation site and their potential to act as atmospheric ice nuclei. Appl. Environ. Microbiol. 75, 5121-5130. doi: 10.1128/AEM.00447-09

Brucker, R. M., Harris, R. N., Schwantes, C. R., Gallaher, T. N., Flaherty, D. C., Lam, B. A., et al. (2008). Amphibian chemical defense: antifungal metabolites of the microsymbiont Janthinobacterium lividum on the salamander Plethodon cinereus. J. Chem. Ecol. 34, 1422-1429. doi: 10.1007/s10886-008-9555-7

Callegan, R. P., Nobre, M. F., McTernan, P. M., Battista, J. R., Navarro-González, R., McKay, C. P., et al. (2008). Description of four novel psychrophilic, ionizing radiation-sensitive Deinococcus species from alpine environments. Int. J. Syst. Evol. Microbiol. 58, 1252-1258. doi: 10.1099/ijs.0.65405-0

Caporaso, J. G., Bittinger, K., Bushman, F. D., Desantis, T. Z., Andersen, G. L., and Knight, R. (2010). PyNAST: a flexible tool for aligning sequences to a template alignment. Bioinformatics 26, 266-267. doi: 10.1093/bioinformatics/btp636
Caquineau, S., Gaudichet, A., Gomes, L., and Legrand, M. (2002). Mineralogy of Saharan dust transported over northwestern tropical Atlantic Ocean in relation to source regions. J. Geophys. Res. Atmos. 107:4251. doi: 10.1029/2000 jd000247

Chanal, A., Chapon, V., Benzerara, K., Barakat, M., Christen, R., Achouak, W., et al. (2006). The desert of Tataouine: an extreme environment that hosts a wide diversity of microorganisms and radiotolerant bacteria. Environ. Microbiol. 8, 514-525. doi: 10.1111/j.1462-2920.2005.00921.x

Chappell, A., Warren, A., O’Donoghue, A., Robinson, A., Thomas, A., and Bristow, C. (2008). The implications for dust emission modeling of spatial and vertical variations in horizontal dust flux and particle size in the Bodele Depression, Northern Chad. J. Geophys. Res. Atmos. 113:D04214. doi: 10.1029/2007JD009032

Chuvochina, M. S., Alekhina, I. A., Normand, P., Petit, J. R., and Bulat, S. A. (2011a). Three events of Saharan dust deposition on the Mont Blanc glacier associated with different snow-colonizing bacterial phylotypes. Microbiology 80, 125-131. doi: 10.1134/S0026261711010061

Chuvochina, M. S., Marie, D., Chevaillier, S., Petit, J.-R., Normand, P., Alekhina, I. A., et al. (2011b). Community variability of bacteria in alpine snow (mont blanc) containing saharan dust deposition and their snow colonisation potential. Microb. Environ. 26, 237-247. doi: 10.1264/jsme2. ME11116

Claquin, T., Schulz, M., and Balkanski, Y. J. (1999). Modeling the mineralogy of atmospheric dust sources. J. Geophys. Res. 104, 22243. doi: 10.1029/1999JD900416

Collaud Coen, M., Weingartner, E., Schaub, D., Hueglin, C., Corrigan, C., Henning, S., et al. (2004). Saharan dust events at the Jungfraujoch: detection by wavelength dependence of the single scattering albedo and first climatology analysis. Atmos. Chem. Phys. 4, 2465-2480. doi: 10.5194/acp-4-246 5-2004

Conen, F., Rodríguez, S., Hüglin, C., Henne, S., Herrmann, E., Bukowiecki, N., et al. (2015). Atmospheric ice nuclei at the high-altitude observatory Jungfraujoch, Switzerland. Tellus B 67:25014. doi: 10.3402/tellusb.v67.25014

Crits-Christoph, A., Robinson, C. K., Barnum, T., Fricke, W. F., Davila, A. F., Jedynak, B., et al. (2013). Colonization patterns of soil microbial communities in the Atacama Desert. Microbiome 1, 28. doi: 10.1186/2049-2618-1-28

D’Almeida, G. A. (1986). A model for saharan dust transport. J. Appl. Meteorol. Climatol. 25, 903-916.

Darwin, C. (1846). An account of the fine dust which often falls on vessels in the Atlantic Ocean. Q. J. Geol. Soc. Lond. 2, 26-30. doi: 10.1144/GSL.JGS.1846.002.01-02.09

Debruyn, J. M., Nixon, L. T., Fawaz, M. N., Johnson, A. M., and Radosevich, M. (2011). Global biogeography and quantitative seasonal dynamics of Gemmatimonadetes in soil. Appl. Environ. Microbiol. 77, 6295-6300. doi: 10.1128/AEM.05005-11

De Deckker, P., Munday, C. I., Brocks, J., O’Loingsigh, T., Allison, G. E., Hope, J., et al. (2014). Characterisation of the major dust storm that traversed over eastern Australia in September 2009; a multidisciplinary approach. Aeolian Res. 15, 133-149. doi: 10.1016/j.aeolia.2014.07.003

De Groot, A., Chapon, V., Servant, P., Christen, R., Saux, M. F., Sommer, S., et al. (2005). Deinococcus deserti sp. nov., a gamma-radiation-tolerant bacterium isolated from the Sahara Desert. Int. J. Syst. Evol. Microbiol. 55, 2441-2446. doi: 10.1099/ijs.0.63717-0

Deleon-Rodriguez, N., Lathem, T. L., Rodriguez, R. L., Barazesh, J. M., Anderson, B. E., Beyersdorf, A. J., et al. (2013). Microbiome of the upper troposphere: species composition and prevalence, effects of tropical storms, and atmospheric implications. Proc. Natl. Acad. Sci. U.S.A. 110, 2575-2580. doi: $10.1073 /$ pnas. 1212089110 
Després, V. R., Huffman, J. A., Burrows, S. M., Hoose, C., Safatov, A. S., Buryak, G., et al. (2012). Primary biological aerosol particles in the atmosphere: a review. Tellus B Chem. Phys. Meteorol. 64:15598. doi: 10.3402/tellusb.v64i0.15598

Dimmick, R. L., Straat, P. A., Wolochow, H., Levin, G. V., Chatigny, M. A., and Schrot, J. R. (1975). Evidence for metabolic activity of airborne bacteria. J. Aerosol Sci. 6, 387-393. doi: 10.1016/0021-8502(75)90054-3

Draxler, R. R., and Rolph, G. D. (2003). HYSPLIT (Hybrid Single-Particle Lagrangian Integrated Trajectory) Model, NOAA Air Resources Laboratory. Silver Spring, MD. Available online at: http://www.arl.noaa.gov/ready/hysplit4. html

Drees, K. P., Neilson, J. W., Betancourt, J. L., Quade, J., Henderson, D. A., Pryor, B. M., et al. (2006). Bacterial community structure in the hyperarid core of the Atacama Desert, Chile. Appl. Environ. Microbiol. 72, 7902-7908. doi: 10.1128/AEM.01305-06

Edgar, R. C. (2013). UPARSE: highly accurate OTU sequences from microbial amplicon reads. Nat. Methods 10, 996-998. doi: 10.1038/nmeth.2604

Elbert, W., Taylor, P. E., Andreae, M. O., and Poschl, U. (2007). Contribution of fungi to primary biogenic aerosols in the atmosphere: wet and dry discharged spores, carbohydrates, and inorganic ions. Atmos. Chem. Phys. 7, 4569-4588. doi: 10.5194/acp-7-4569-2007

Evans, R. D., Jefferson, I. F., Kumar, R., O'Hara-Dhand, K., and Smalley, I. J. (2004). The nature and early history of airborne dust from North Africa; in particular the Lake Chad basin. J. Afr. Earth Sci. 39, 81-87. doi: 10.1016/j.jafrearsci.2004.06.001

Fahlgren, C., Hagström, A., Nilsson, D., and Zweifel, U. L. (2010). Annual variations in the diversity, viability, and origin of airborne bacteria. Appl. Environ. Microbiol. 76, 3015-3025. doi: 10.1128/AEM.02092-09

Favet, J., Lapanje, A., Giongo, A., Kennedy, S., Aung, Y. Y., Cattaneo, A., et al. (2013). Microbial hitchhikers on intercontinental dust: catching a lift in Chad. ISME J. 7, 850-867. doi: 10.1038/ismej.2012.152

Fierer, N., Leff, J. W., Adams, B. J., Nielsen, U. N., Bates, S. T., Lauber, C. L., et al. (2012). Cross-biome metagenomic analyses of soil microbial communities and their functional attributes. Proc. Natl. Acad. Sci. U.S.A. 109, 21390-21395. doi: $10.1073 /$ pnas. 1215210110

Flentje, H., Briel, B., Beck, C., Collaud Coen, M., Fricke, M., Cyrys, J., et al. (2015). Identification and monitoring of Saharan dust: an inventory representative for south Germany since 1997. Atmos. Environ. 109, 87-96. doi: 10.1016/j.atmosenv.2015.02.023

Frey, B., Rieder, S. R., Brunner, I., Plötze, M., Koetzsch, S., Lapanje, A., et al. (2010). Weathering-associated bacteria from the Damma glacier forefield: physiological capabilities and impact on granite dissolution. Appl. Environ. Microbiol. 76, 4788-4796. doi: 10.1128/AEM.00657-10

González-Toril, E., Amils, R., Delmas, R. J., Petit, J.-R., Komárek, J., and Elster, J. (2009). Bacterial diversity of autotrophic enriched cultures from remote, glacial Antarctic, Alpine and Andean aerosol, snow and soil samples. Biogeosciences 6, 33-44. doi: 10.5194/bg-6-33-2009

Goodison, B. E., Ferguson, H. L., and McKay, G. A. (1981). "Measurement and data analysis," in Handbook of Snow: Principles, Processes, Management and Use, eds D. M. Gray and D. H. Male (Caldwell, NJ: The Blackburn Press), 191-274.

Gorbushina, A. A., Kort, R., Schulte, A., Lazarus, D., Schnetger, B., Brumsack, H. J., et al. (2007). Life in Darwin's dust: intercontinental transport and survival of microbes in the nineteenth century. Environ. Microbiol. 9, 2911-2922. doi: 10.1111/j.1462-2920.2007.01461.x

Goudie, A., and Middleton, N. (2006). Desert Dust in the Global System. Berlin; New York, NY: Springer.

Griffin, D., Kellogg, C., Garrison, V., Lisle, J., Borden, T., and Shinn, E. (2003). Atmospheric microbiology in the northern Caribbean during African dust events. Aerobiologia 19, 143-157. doi: 10.1023/B:AERO.0000006530. $32845.8 \mathrm{~d}$

Griffin, D. W. (2007). Atmospheric movement of microorganisms in clouds of desert dust and implications for human health. Clin. Microbiol. Rev. 20, 459-477, table of contents. doi: 10.1128/cmr.00039-06

Griffin, D. W., Kubilay, N., Kocak, M., Gray, M. A., Borden, T. C., and Shinn, E. A. (2007). Airborne desert dust and aeromicrobiology over the Turkish Mediterranean coastline. Atmos. Environ. 41, 4050-4062. doi: 10.1016/j.atmosenv.2007.01.023

Griffiths, A. D., Conen, F., Weingartner, E., Zimmermann, L., Chambers, S. D., Williams, A. G., et al. (2014). Surface-to-mountaintop transport characterised by radon observations at the Jungfraujoch. Atmos. Chem. Phys. 14, 12763-12779. doi: 10.5194/acp-14-12763-2014

Hanada, S., and Sekiguchi, Y. (2014). "The phylum gemmatimonadetes," in The Prokaryotes, eds E. Rosenberg, E. Delong, S. Lory, E. Stackebrandt, and F. Thompson (Berlin; Heidelberg: Springer), 677-681.

Herlemann, D. P., Labrenz, M., Jürgens, K., Bertilsson, S., Waniek, J. J., and Andersson, A. F. (2011). Transitions in bacterial communities along the $2000 \mathrm{~km}$ salinity gradient of the Baltic Sea. ISME J. 5, 1571-1579. doi: 10.1038/ismej.2011.41

Hervas, A., Camarero, L., Reche, I., and Casamayor, E. O. (2009). Viability and potential for immigration of airborne bacteria from Africa that reach high mountain lakes in Europe. Environ. Microbiol. 11, 1612-1623. doi: 10.1111/j.1462-2920.2009.01926.x

Hervas, A., and Casamayor, E. O. (2009). High similarity between bacterioneuston and airborne bacterial community compositions in a high mountain lake area. FEMS Microbiol. Ecol. 67, 219-228. doi: 10.1111/j.1574-6941.2008.0 0617.x

Hill, K. A., Shepson, P. B., Galbavy, E. S., Anastasio, C., Kourtev, P. S., Konopka, A., et al. (2007). Processing of atmospheric nitrogen by clouds above a forest environment. J. Geophys. Res. 112:D11301. doi: 10.1029/2006jd008002

Hiranuma, N., Möhler, O., Yamashita, K., Tajiri, T., Saito, A., Kiselev, A., et al. (2015). Ice nucleation by cellulose and its potential contribution to ice formation in clouds. Nat. Geosci. 8, 273-277. doi: 10.1038/ngeo2374

Hirsch, P., Gallikowski, C. A., Siebert, J., Peissl, K., Kroppenstedt, R., Schumann, P., et al. (2004). Deinococcus frigens sp. nov., Deinococcus saxicola sp. nov., and Deinococcus marmoris sp. nov., low temperature and draught-tolerating, UV-resistant bacteria from continental Antarctica. Syst. Appl. Microbiol. 27, 636-645. doi: 10.1078/0723202042370008

Jaenicke, R. (2005). Abundance of cellular material and proteins in the atmosphere. Science 308, 73. doi: 10.1126/science.1106335

Jeon, E. M., Kim, H. J., Jung, K., Kim, J. H., Kim, M. Y., Kim, Y. P., et al. (2011). Impact of Asian dust events on airborne bacterial community assessed by molecular analyses. Atmos. Environ. 45, 4313-4321. doi: 10.1016/j.atmosenv.2010.11.054

Katra, I., Arotsker, L., Krasnov, H., Zaritsky, A., Kushmaro, A., and Ben-Dov, E. (2014). Richness and diversity in dust stormborne biomes at the southeast mediterranean. Sci. Rep. 4, 5265. doi: 10.1038/srep05265

Kim, S. J., Shin, S. C., Hong, S. G., Lee, Y. M., Lee, H., Lee, J., et al. (2012). Genome sequence of Janthinobacterium sp. strain PAMC 25724, isolated from alpine glacier cryoconite. J. Bacteriol. 194, 2096. doi: 10.1128/JB.00096-12

Kindt, R., and Coe, R. (2005). Tree Diversity Analysis: A Manual and Software for Common Statistical Methods for Ecological and Biodiversity Studies. Nairobi: World Agrofirestry Centre.

Krueger, B. J., Grassian, V. H., Cowin, J. P., and Laskin, A. (2004). Heterogeneous chemistry of individual mineral dust particles from different dust source regions: the importance of particle mineralogy. Atmos. Environ. 38, 6253-6261. doi: 10.1016/j.atmosenv.2004.07.010

Kulkarni, P., Baron, P. A., and Willeke, K. (eds.). (2011). "Introduction to aerosol characterization," in Aerosol Measurement: Principles, Techniques, and Applications, 3rd Edition (Hoboken, NJ: John Wiley \& Sons, Inc.). doi: 10.1002/9781118001684.ch1

Labhart, T. P. (2001). Geologie der Schweiz. Thun: Ott.

Lazzaro, A., Wismer, A., Schneebeli, M., Erny, I., and Zeyer, J. (2015). Microbial abundance and community structure in a melting alpine snowpack. Extremophiles 19, 631-642. doi: 10.1007/s00792-015-0744-3

Legendre, P., and Anderson, M. J. (1999). Distance-based redundancy analysis: testing multispecies responses in multifactorial ecological experiments Ecol. Monogr. 69, 512-512. doi: 10.1890/00129615(1999)069[0001:DBRATM]2.0.CO;2

Letunic, I., and Bork, P. (2011). Interactive Tree Of Life v2: online annotation and display of phylogenetic trees made easy. Nucleic Acids Res. 39, W475-W478. doi: 10.1093/nar/gkr201

Liu, Y., Yao, T., Jiao, N., Kang, S., Zeng, Y., and Liu, X. (2009). Abundance and diversity of snow bacteria in two glaciers at the Tibetan Plateau. Front. Earth Sci. China 3, 80-90. doi: 10.1007/s11707-009-0016-6

Mandal, J., and Brandl, H. (2011). Bioaerosols in indoor environment - a review with special reference to residential and occupational locations. Open Environ. Biol. Monit. J. 4, 83-96. doi: 10.2174/1875040001104010083 
McMurdie, P. J., and Holmes, S. (2013). phyloseq: an R package for reproducible interactive analysis and graphics of microbiome census data. PLOS ONE 8:e61217. doi: 10.1371/journal.pone.0061217

Möhler, O., Demott, P. J., Vali, G., and Levin, Z. (2007). Microbiology and atmospheric processes: the role of biological particles in cloud physics. Biogeosciences 4, 1059-1071. doi: 10.5194/bg-4-1059-2007

Moreno, T. (2003). The geology of ambient aerosols: characterising urban and rural/coastal silicate PM10-2.5 and PM2.5 using high-volume cascade collection and scanning electron microscopy. Atmos. Environ. 37, 4265-4276. doi: 10.1016/S1352-2310(03)00534-X

Moreno, T., Querol, X., Castillo, S., Alastuey, A., Cuevas, E., Herrmann, L., et al. (2006). Geochemical variations in aeolian mineral particles from the Sahara-Sahel Dust Corridor. Chemosphere 65, 261-270. doi: 10.1016/j.chemosphere.2006.02.052

Morris, C. E., Sands, D. C., Bardin, M., Jaenicke, R., Vogel, B., Leyronas, C., et al. (2011). Microbiology and atmospheric processes: research challenges concerning the impact of airborne micro-organisms on the atmosphere and climate. Biogeosciences 8, 17-25. doi: 10.5194/bg-8-17-2011

Nicolás, J. F., Crespo, J., Yubero, E., Soler, R., Carratalá, A., and Mantilla, E. (2014). Impacts on particles and ozone by transport processes recorded at urban and high-altitude monitoring stations. Sci. Total Environ. 466-467, 439-446. doi: 10.1016/j.scitotenv.2013.07.060

Oksanen, J., Blanchet, F. G., Kindt, R., Legendre, P., Minchin, P. R., O’Hara, R. et al. (2015). vegan: Community Ecology Package. R package version 2.3-2. Available online at: http://CRAN.R-project.org/package=vegan

Pantanella, F., Berlutti, F., Passariello, C., Sarli, S., Morea, C., and Schippa, S. (2007). Violacein and biofilm production in Janthinobacterium lividum. J. Appl. Microbiol. 102, 992-999. doi: 10.1111/j.1365-2672.2006.03155.x

Papayannis, A., Amiridis, V., Mona, L., Tsaknakis, G., Balis, D., Bösenberg, J., et al. (2008). Systematic lidar observations of Saharan dust over Europe in the frame of EARLINET (2000-2002). J. Geophys. Res. 113:D10204. doi: 10.1029/2007jd009028

Peter, H., Hörtnagl, P., Reche, I., and Sommaruga, R. (2014). Bacterial diversity and composition during rain events with and without Saharan dust influence reaching a high mountain lake in the Alps. Environ. Microbiol. Rep. 6, 618-624. doi: 10.1111/1758-2229.12175

Pointing, S. B., and Belnap, J. (2012). Microbial colonization and controls in dryland systems. Nat. Rev. Microbiol. 10, 551-562. doi: 10.1038/nrmicro2831

Pointing, S. B., Chan, Y., Lacap, D. C., Lau, M. C. Y., Jurgens, J. A., and Farrell, R. L. (2010). Highly specialized microbial diversity in hyper-arid polar desert (vol 106, pg 19964, 2009). Proc. Natl. Acad. Sci. U.S.A. 107, 1254-1254. doi: 10.1073/pnas.0913882107

Polymenakou, P. N. (2012). Atmosphere: a source of pathogenic or beneficial microbes? Atmosphere 3, 87-102. doi: 10.3390/atmos3010087

Polymenakou, P. N., Mandalakis, M., Stephanou, E. G., and Tselepides, A. (2008). Particle size distribution of airborne microorganisms and pathogens during an Intense African dust event in the eastern Mediterranean. Environ. Health Perspect. 116, 292-296. doi: 10.1289/ehp.10684

Price, M. N., Dehal, P. S., and Arkin, A. P. (2010). FastTree 2-approximately maximum-likelihood trees for large alignments. PLOS ONE 5:e9490. doi: 10.1371/journal.pone.0009490

Prospero, J. M., Blades, E., Mathison, G., and Naidu, R. (2005). Interhemispheric transport of viable fungi and bacteria from Africa to the Caribbean with soil dust. Aerobiologia 21, 1-19. doi: 10.1007/s10453-004-5872-7

Rainey, F. A., Ray, K., Ferreira, M., Gatz, B. Z., Nobre, M. F., Bagaley, D., et al. (2005). Extensive diversity of ionizing-radiation-resistant bacteria recovered from Sonoran Desert soil and description of nine new species of the genus Deinococcus obtained from a single soil sample. Appl. Environ. Microbiol. 71, 5225-5235. doi: 10.1128/AEM.71.9.5225-5235.2005

R Core Team (2015). R: A Language and Environment for Statistical Computing. Vienna: R Foundation for Statistical Computing. Available online at: http:// www.R-project.org/

Rime, T., Hartmann, M., Brunner, I., Widmer, F., Zeyer, J., and Frey, B. (2015). Vertical distribution of the soil microbiota along a successional gradient in a glacier forefield. Mol. Ecol. 24, 1091-1108. doi: 10.1111/mec.13051

Romero, O. E., Lange, C. B., Swap, R., and Wefer, G. (1999). Eolian-transported freshwater diatoms and phytoliths across the equatorial Atlantic record: temporal changes in Saharan dust transport patterns. J. Geophys. Res. 104, 3211. doi: 10.1029/1998JC900070

Sánchez De La Campa, A., García-Salamanca, A., Solano, J., De La Rosa, J., and Ramos, J. L. (2013). Chemical and microbiological characterization of atmospheric particulate matter during an intense African dust event in Southern Spain. Environ. Sci. Technol. 47, 3630-3638. doi: 10.1021/ es3051235

Šantl-Temkiv, T., Finster, K., Dittmar, T., Hansen, B. M., Thyrhaug, R., Nielsen, N. W., et al. (2013). Hailstones: a window into the microbial and chemical inventory of a storm cloud. PLoS ONE 8:e53550. doi: 10.1371/journal.pone. 0053550

Scheuvens, D., Schütz, L., Kandler, K., Ebert, M., and Weinbruch, S. (2013). Bulk composition of northern African dust and its source sedimentsA compilation. Earth Sci. Rev. 116, 170-194. doi: 10.1016/j.earscirev.2012. 08.005

Schwikowski, M., Seibert, P., Baltensperger, U., and Gaggeler, H. W. (1995). A study of an outstanding saharan dust event at the high-alpine site jungfraujoch, Switzerland. Atmos. Environ. 29, 1829-1842. doi: 10.1016/13522310(95)00060-C

Segawa, T., Miyamoto, K., Ushida, K., Agata, K., Okada, N., and Kohshima, S. (2005). Seasonal change in bacterial flora and biomass in mountain snow from the Tateyama Mountains, Japan, analyzed by 16S rRNA gene sequencing and real-time PCR. Appl. Environ. Microbiol. 71, 123-130. doi: 10.1128/AEM.71.1.123-130.2005

Shao, Y., Wyrwoll, K.-H., Chappell, A., Huang, J., Lin, Z., McTainsh, G. H., et al. (2011). Dust cycle: an emerging core theme in Earth system science. Aeolian Res. 2, 181-204. doi: 10.1016/j.aeolia.2011.02.001

Smith, D. J., Griffin, D. W., and Schuerger, A. C. (2009). Stratospheric microbiology at $20 \mathrm{~km}$ over the Pacific Ocean. Aerobiologia 26, 35-46. doi: 10.1007/s10453009-9141-7

Sodemann, H., Palmer, A. S., Schwierz, C., Schwikowski, M., and Wernli, H. (2006). The transport history of two Saharan dust events archived in an Alpine ice core. Atmos. Chem. Phys. 6, 667-688. doi: 10.5194/acp-6667-2006

Solomon, S., Daniel, J. S., Neely Iii, R. R., Vernier, J.-P., Dutton, E. G., and Thomason, L. W. (2011). The persistently variable "background" stratospheric aerosol layer and global climate change. Science 333, 866-870. doi: 10.1126/science. 1206027

Thevenon, F., Anselmetti, F. S., Bernasconi, S. M., and Schwikowski, M. (2009). Mineral dust and elemental black carbon records from an Alpine ice core (Colle Gnifetti glacier) over the last millennium. J. Geophys. Res. Atmos. 114:D17102. doi: 10.1029/2008jd011490

Tong, Y. Y., and Lighthart, B. (1997). Solar radiation is shown to select for pigmented bacteria in the ambient outdoor atmosphere. Photochem. Photobiol. 65, 103-106. doi: 10.1111/j.1751-1097.1997.tb01884.x

Yamaguchi, N., Park, J., Kodama, M., Ichijo, T., Baba, T., and Nasu, M. (2014). Changes in the airborne bacterial community in outdoor environments following Asian dust events. Microb. Environ. 29, 82-88. doi: 10.1264/jsme2.ME13080

Yuan, M., Zhang, W., Dai, S., Wu, J., Wang, Y., Tao, T., et al. (2009). Deinococcus gobiensis sp. nov., an extremely radiation-resistant bacterium. Int. J. Syst. Evol. Microbiol. 59, 1513-1517. doi: 10.1099/ijs.0.004523-0

Zhang, H. (2003). Gemmatimonas aurantiaca gen. nov., sp. nov., a Gramnegative, aerobic, polyphosphate-accumulating micro-organism, the first cultured representative of the new bacterial phylum Gemmatimonadetes phyl. nov. Int. J. Syst. Evol. Microbiol. 53, 1155-1163. doi: 10.1099/ijs.0.02520-0

Conflict of Interest Statement: The authors declare that the research was conducted in the absence of any commercial or financial relationships that could be construed as a potential conflict of interest.

Copyright () 2015 Meola, Lazzaro and Zeyer. This is an open-access article distributed under the terms of the Creative Commons Attribution License (CC BY). The use, distribution or reproduction in other forums is permitted, provided the original author(s) or licensor are credited and that the original publication in this journal is cited, in accordance with accepted academic practice. No use, distribution or reproduction is permitted which does not comply with these terms. 